\title{
Insights into mixed contaminants interactions and its implication for heavy metals and metalloids mobility, bioavailability and risk assessment
}

\author{
Cipullo S. ${ }^{1}$, Snapir B. ${ }^{1}$, Tardif, S. ${ }^{2}$,Campo P. ${ }^{1}$, Prpich G. ${ }^{3}$, Coulon F. ${ }^{1 *}$ \\ ${ }^{1}$ Cranfield University, School of Water, Energy and Environment, Cranfield, MK43 OAL, UK \\ ${ }^{2}$ University of Copenhagen, Department of Plant and Environmental Sciences Microbial \\ Ecology and Biotechnology, Denmark \\ ${ }^{3}$ University of Virginia, Department of Chemical Engineering, USA \\ *Corresponding author: f.coulon@ cranfield.ac.uk, +44 (0)1234 754981
}

\begin{abstract}
:
Mobility of heavy metals at contaminated sites is mainly influenced by the soil physicochemical properties and environmental conditions, therefore assessing heavy metals (HMs) and metalloids fractionation can provide insights into their potential risk and the mechanisms that regulate bioavailability. A 12-months mesocosms experiment was setup to investigate the effect of physicochemical factors $(\mathrm{pH}$, moisture, and temperature) and weathering (time) on HMs and metalloids fractionation in three different multi-contaminated soil matrices (low, medium, and high contamination) collected from a soil treatment facility located in the United Kingdom, and two rural contaminated soil samples. The study demonstrates that even though $\mathrm{Pb}$ and $\mathrm{Zn}$ were found associated with the exchangeable fraction in the soil with the highest contamination (total average $\mathrm{Pb} 3400 \mathrm{mg} / \mathrm{kg}$, and total average $\mathrm{Zn} 2100 \mathrm{mg} / \mathrm{kg}$ in Soil C), neither the condition applied nor the weathering caused an increase in their mobility. Although it was expected that lower $\mathrm{pH}$ (4.5) would favours the dissociation of HMs and metalloids, no significant differences were observed, potentially due to the initial alkaline $\mathrm{pH}$ of the genuine-contaminated soil samples. The results show that even though total concentration of $\mathrm{Pb}, \mathrm{Cu}$, and $\mathrm{Zn}$ exceed the soil standards and guideline values, HMs were predominantly associated with the non-exchangeable fraction, while only $5 \%$ were dissolved in the pore water fraction (potentially bioavailable). In addition, the
\end{abstract}


mobility and bioavailability of HMs remained constant over the 12 months monitoring, suggesting that these soils pose negligible risk to the environment.

Keywords: Chemical mixtures, Fractionation, Mobility, Ageing, Risk Assessment

\section{Introduction}

Anthropogenic activities such as mining, waste disposal, combustion of leaded fuels, the use of fertilizers and pesticides, and petrochemical spills all contribute to the presence, accumulation, and persistence of heavy metals (HMs) in soil (Tóth et al., 2016; Suresh et al., 2012, Wuana and Okieimen, 2011). While organic contaminants might be degraded as they persist in the environment, inorganic contaminants, such as heavy metals and metalloids, are non-degradable and display long-term persistence in soils (Lu et al., 2017), which can potentially cause risk for plants, animals, and humans (Bolan et al., 2014).

European environmental regulatory frameworks, to manage HMs pollution, define risk based on the total extractable concentration of metals in soil. This approach does not consider how likely an HM is to be bioavailable, which can lead to an over/under estimation of risk (Cipullo et al., 2018). In relation to contaminated land risk assessment and remediation, bioavailability can be interpreted as the fraction of contaminant that is freely available in the environment (not sorbed or sequestrated), and mobile (extractable by mild extraction), thus the most likely to lead to receptor exposure (Adedigba and Semple, 2015; Dean and Scott, 2004).

Sorption and desorption are the main processes controlling bioavailability of HMs (Caporale and Violante, 2016); in particular soil components responsible for the sorption includes; amorphous materials, silicates, clay minerals, , carbonates, and organic matter (Leleyter et al., 2012). How a HM interacts with the different soil compartments will influence its bioavailability, and it is bioavailability that can inform the likelihood that a HM might leach 
into the broader environment (Ashraf et al., 2012). For example, HMs that are dissolved in pore water can be easily mobilized, and are considered readily available for uptake by plants (Chang et al., 2014) or available for interaction with biological systems (Hodson et al., 2011), while those dissolved in labile fractions are potentially bioavailable, if physico-chemical conditions were to change (e.g pH decrease) (Di Bonito et al., 2018). Many physico-chemical factors such as soil $\mathrm{pH}$, composition, organic carbon content, and redox potential, can impact partitioning between soil-solid phase and pore water, which will consequently have an impact on HMs bioavailability (Islam et al., 2015; Venegas et al., 2016). In contrast, HMs associated with non-exchangeable or non-mobile soil fractions are characterized by a stronger binding (weaker reversibility), therefore unlikely to leach into the surrounding environment.

Despite the recent shift toward a risk-based approaches for assessing contaminated sites, risk characterization remains a conservative approach (Harmsen and Naidu, 2013; Naidu et al., 2015; Ortega-Calvo et al., 2015), because it relies on total contaminant concentration, rather than assessing the fraction of the total (bioavailable) that can potentially interact with biological and environmental targets. For bioavailability to be implemented and support regulatory decisions, the bioavailable estimation should rely on standardized methods, however, to date there exists no systematic method of assessment (Alvarez et al., 2011; R. Y. Kim et al., 2015). A number of techniques have been developed over the past two decades, and are still used to estimate HMs bioavailability in soil; including diffusive gradient in thin films (Agbenin and Welp, 2012; Menegário et al., 2017; Parker et al., 2016; Ren et al., 2015), ion exchange (Ge et al., 2005; Qian and Schoenau, 2002), single-step extractions (R. Y. Kim et al., 2015; Pinto et al., 2015; Sakan et al., 2016), and sequential extractions (Cox et al., 2013; Fernández-Ondoño et al., 2017; Palumbo-Roe et al., 2013; Reis et al., 2014; Sungur et al., 2014). Sequential extractions, in particular, are simple low cost methods, that can be applied to different soil types (Rosado et al., 2016), and can help understanding HMs and 
metalloids leachability, solubility, and mobility (Kaakinen et al., 2015), providing the most information about the fate, transport, and behaviour of HMs in soil. However, most studies focus on (1) assessing effects and toxicity of one contaminant in isolation (Cui et al., 2005), (2) using sequential chemical extraction on synthetic models or spiked samples (R.-Y. Kim et al., 2015; Ma et al., 2015) rather than genuine contaminated soil samples (Ma et al., 2015). Limitations associated with these approaches include; metal transfer among phases (Bermond, 1992) when performing sequential extractions resulting in an overestimation of metals concentration and risk, and the inability of an artificial contamination to reproduce the actual geochemistry encountered in real site conditions (Ribeiro and Mexia, 1997). While it is challenging to establish a one-size fits all approach for assessing HMs behaviour in contaminated soil, the choice of procedure should be based on a more realistic prediction of elemental mobility and characterisation of their association with the soil matrix.

In this study a modified version of a non-specific sequential extraction method coupled to chemometric analysis known as the Chemometric Identification of Substrates and Element Distributions (CISED), was used and applied to five different genuine contaminated soils. Our objectives were (1) to apply a sequential extraction technique in genuine-contaminated soil samples and identify the common soil phases, (2) to evaluate the spatial distribution of HMs/metalloids and potential changes over time in order to ascertain the bioavailability of HMs/metalloids and potential risk, (3) to determine the influence of different physicochemical factors on HMs/metalloids solid phase distribution and bioavailability, and (4) to evaluate the effect of co-occurrence of hydrocarbons on HMs/metalloids partitioning in soil samples. The novelty of this study lies in the fact that it highlights the importance of taking into account the effects of a range of environmental stressor conditions ( $\mathrm{pH}$, moisture, and temperature) and weathering (time), on HMs/metalloids potentially labile fractions; including both dissolved elements (pore water), and exchangeable fraction in genuine co-contaminated 
soil samples. A special emphasis on the effectiveness of this protocol with multicontaminated samples of different nature (with and without stabilisation treatment), origins (industrial and rural), and with a wide range of HMs contents has also been verified. This information can be used as additional lines of evidence to support risk-based decisions about endpoint remediation and to evaluate potential reuse of remediated soil.

\section{Materials and methods}

\subsection{Sample collection and preparation}

Since soil contaminants are often present in the environment in a complex mixture, including both inorganic and organic compounds as by-products of industrial activities (Wawra et al., 2018), this study investigates five multi-contaminated soil samples. Three genuine contaminated soils, denoted as Soil A, Soil B (treated), and Soil C, were collected from a soil treatment facility located in the United Kingdom. Information regarding original location of the soil samples collected, and specific details regarding the treatment applied (soil B), were not disclosed to maintain anonymity and confidentiality. Two additional samples were collected from a rural site contaminated by HMs/metalloids and diesel range organic (DRO) compounds $\left(\mathrm{nC}_{10}-\mathrm{nC}_{24}\right)$ (Soil D), and $\mathrm{HMs}$ /metalloids mineral oil range organic (MRO) compounds $\left(\mathrm{nC}_{22}-\mathrm{nC}_{34}\right)$ (Soil E). The mutual presence of organic and inorganic contaminants in these soil samples could potentially enhance (or inhibit) HMs transport by competitive sorption, where metal-organic complexes are formed, limiting their capacity to interact with soil-surfaces (Wuana et al., 2014). Information about the soil matrix and type of contamination is provided in Table 1.

All samples were collected randomly by disturbing sampling soil, up to a depth of $30 \mathrm{~cm}$ and immediately stored at $4^{\circ} \mathrm{C}$ to minimise biological transformation and other chemical reactions. Soil A was a sandy loam soil heavily contaminated with tar and HMs (Total 
Petroleum Hydrocarbons (TPHs) $>1000 \mathrm{mg} / \mathrm{kg}$ of soil, HMs $>800 \mathrm{mg} / \mathrm{kg}$ of soil); Soil B was similar to Soil A except that former was stabilised with a cement-binder mixture. Soil C was a sandy loam soil presenting low petroleum hydrocarbon content (TPHs $<1000 \mathrm{mg} / \mathrm{kg}$ ) but high concentration of HMs (HMs > $6200 \mathrm{mg} / \mathrm{kg}$ of soil). In addition, two different rural soils contaminated with HMs and diesel (Soil D), and HMs and mineral oil (Soil E) (TPHs < $500 \mathrm{mg} / \mathrm{kg}$ of soil, $\mathrm{HMs}>800 \mathrm{mg} / \mathrm{kg}$ of soil) were used.

\subsection{Mesocosms experimental design}

Duplicate soil mesocosms were set up for each condition studied using a $10 \mathrm{~L}$ polypropylene bucket. Each bucket was filled with approximately $5 \mathrm{~kg}$ of loosely packed soil, and amended with buffer or moisture as according to the experimental conditions described in Table 2 . All experiments were tested over a 12 month period. Different temperature conditions were simulated by storing samples in controlled temperature rooms at $20^{\circ} \mathrm{C}$ and $4^{\circ} \mathrm{C}$. Those experiments treated under outdoor conditions were placed outside and subject to seasonal UK temperature variations. Soil samples were amended with a mixture of sulphuric acid and water to achieve different $\mathrm{pH}$ conditions. Redox reactions are a relevant aspect of soil chemistry as they can affect speciation and solubility of heavy metals and metalloids in soil, altering the biochemistry of soils (Kuhlbusch TA.J. and Crutzen PJ., 2018; Tuor, 1990) . Therefore this experiment was conducted in presence of atmospheric $\mathrm{O}_{2}$ for all the soil samples and all the condition tested. Moisture content was maintained by adding deionized water up to 20 and $70 \%$ of the soils' maximum water holding capacity (WHC) and moisture content was re-assessed bi-monthly. The moisture content for Condition 6, which was kept outdoors, was not altered. Soil samples were taken from each mesocosm at 0,6 , and 12 months' time. All samples were analysed for pseudo-total and bioavailable HMs content. 


\subsection{Physico-chemical characterisation}

Soil samples were sieved using a $2 \mathrm{~mm}$ mesh to separate large particles (e.g. roots, stems, and pebbles). Each soil samples were divided and processed for analysis in the following way: (1) $5 \mathrm{~g}$ of sample was used for dry matter and water content analysis, (2) a volume of $225 \mathrm{~cm}^{3}$ of sample was used for water holding capacity measurement. Additionally, a large aliquot of each soil sample, approximately $500 \mathrm{~g}$, was air dried for 7 days to perform multiple analysis where individual air-dried samples were used as follow: (1) $10 \mathrm{ml}$ of sample (measured with $10 \mathrm{ml}$ brass scoop) was used for $\mathrm{pH}$ analysis, (2) $10 \mathrm{ml}$ of sample was used for particle size distribution, (3) $5 \mathrm{~g}$ of sample was used for loss of ignition, (3) $0.001 \mathrm{mg}$ was used Total Nitrogen (TN) and Total carbon (TC), (4) $5 \mathrm{~g}$ of sample was used for Total phosphorous (TP) and available phosphorous (AP).

For dry matter and water content analysis, $5 \mathrm{~g}$ of fresh soil samples were weighted in a crucible and dried at $105^{\circ} \mathrm{C} \pm 5^{\circ} \mathrm{C}$ for $24 \mathrm{hrs}$; the difference in mass of an amount of soil before and after drying was used to calculate the dry matter and water contents on a mass basis. Maximum water holding capacity was determined according to ISO 11274 (1998). Soil samples were air-dried and then flooded on a wetting-up bath for 7 days; the mass recorded was used to determine the moisture content at saturation.

Soil $\mathrm{pH}$ was measured using a $\mathrm{pH}$ meter. Samples were prepared by adding distilled water to create a slurry (1 part soil: 5 parts water). Samples were shaken for $60 \mathrm{~min}$ and allowed to equilibrate for an additional 30 min before $\mathrm{pH}$ was measured (ISO 10390:2005).

Particle size distribution was determined by the sieving and sedimentation method. In short, soil organic matter was discomposed with hydrogen peroxide and the resulting slurry dispersed with a buffered sodium hexametaphosphate solution, then the different particle size fractions was determined by a combination of sieving and sedimentation (ISO 11277:2009). 
The soil organic content was determined by loss of ignition (LOI); air-dried soil was dehydrated at $105^{\circ} \mathrm{C}$ then ashed at $450^{\circ} \mathrm{C}$, loss on ignition is expressed as a percentage of the dehydrated sample (British Standard BS EN 13039:2000).

Total carbon and total nitrogen in soil material were determined by heating to a temperature of at least $900^{\circ} \mathrm{C}$ in the presence of oxygen gas, the amount of nitrogen and carbon is then measured by a thermal conductivity detector (TCD) (British Standard BS EN 13654-2:2001).

Total phosphorous was measured with a hydrochloric/nitric acid mixture extraction; the phosphorus content was then determined by a spectrometric measurement in solution (ISO 11047:1998). Available phosphorous was measured by treating the soil with a $0.5 \mathrm{~mol} \mathrm{~L}^{-1}$ sodium hydrogen carbonate solution at $\mathrm{pH} 8.5$, the extract is then analysed by a spectrometric method (ISO 11263:1994).

\subsection{Extraction and quantification of total petroleum hydrocarbons}

The method used to determine total petroleum hydrocarbons (TPHs), including both aliphatic (ALKs) and aromatic (PAHs) fractions in soil, was based on the Risdon et al. (2008) procedure. Briefly $2.5 \mathrm{~g}$ of soil were weighted and chemically dried with $2 \mathrm{~g}$ anhydrous sodium sulphate. At the same time as weighing samples for extraction, moisture content was measured to provide the appropriate correction factors. The chemically dried samples were extracted for TPHs content with a mixture of $10 \mathrm{ml}$ of dichloromethane: hexane sonicated for $20 \mathrm{~min}$ at room temperature, and shaken at $150 \mathrm{~g}$ for $16 \mathrm{~h}$. On the following day, samples were again sonicated for $20 \mathrm{~min}$ at room temperature and centrifuged at $2000 \mathrm{~g}$ for $10 \mathrm{~min}$ to separate the solid and liquid fractions. The liquid fraction was then cleaned onto a $6 \mathrm{ml} \mathrm{SPE}$ DSC-Si silica tubes, concentrated to dryness (on ice) under a gentle stream of nitrogen, and re-suspended in $0.5 \mathrm{ml}$ DCM:Hex (1:1) with addition $0.5 \mathrm{ml}$ of internal standards comprised of a deuterated alkanes mix $\left(\mathrm{C} 10^{\mathrm{d} 22}, \mathrm{C} 19^{\mathrm{d} 40}\right.$ and $\left.\mathrm{C} 30^{\mathrm{d} 62}\right)$ and deuterated PAH mix $(1,4-$ 
dichlorobenzene ${ }^{\mathrm{d} 4}$, naphthalene ${ }^{\mathrm{d} 8}$, anthracene ${ }^{\mathrm{d} 10}$, chrysene ${ }^{\mathrm{d} 12}$ and perylene ${ }^{\mathrm{d} 12}$ ) at $10 \mu \mathrm{g} \mathrm{ml}^{-1}$ each, respectively. Concentration of petroleum hydrocarbons were identified and quantified by gas chromatography-mass spectrometry (GC-MS) using an Agilent gas chromatograph coupled to a Turbomass Gold mass spectrometer operated at $70 \mathrm{eV}$ in positive ion mode. The column used was a Restek fused silica capillary column (30 x $0.25 \mathrm{~mm}$ internal diameter) coated with RTX®-5MS (0.25 $\mu \mathrm{m}$ film thickness). Splitless injection with a sample volume of $1 \mu \mathrm{l}$ was applied. The oven temperature was increased from $60^{\circ} \mathrm{C}$ to $220^{\circ} \mathrm{C}$ at $20^{\circ} \mathrm{C} \mathrm{min}{ }^{-1}$ then to $310^{\circ} \mathrm{C}$ at $6^{\circ} \mathrm{C} \mathrm{min}^{-1}$ and held at this temperature for $15 \mathrm{~min}$; for a total run time of 38 min. The mass spectrometer was operated using the full scan mode (range $\mathrm{m} / \mathrm{z}$ 50-500) for quantitative analysis of target aliphatic and aromatic hydrocarbons. For each compound, quantification was performed by integrating the peak at specific $\mathrm{m} / \mathrm{z}$. External multilevel calibrations were carried out using alkane (standard solution $\left(\mathrm{C}_{8}-\mathrm{C}_{40}\right)$ Sigma Aldrich, Dorset, UK) and PAHs (EPA 525 PAH Mix A; Sigma Aldrich, Dorset, UK) standards, the concentration of which ranged from 2.5 to $50 \mu \mathrm{g} \mathrm{ml}^{-1}$ respectively. For quality control, blank controls and a $500 \mu \mathrm{g} \mathrm{mL}^{-1}$ diesel standard solution (ASTM $\mathrm{C}_{12}-\mathrm{C}_{60}$ quantitative, Supelco) were analyzed every 20 samples. The variation of the reproducibility of extraction and quantification of soil samples were determined by successive injections $(n=7)$ of the same sample and estimated to $\pm 8 \%$. In addition, duplicate reagent control and reference material were systematically used. The reagent control was treated following the same procedure as the samples without adding soil sample. The reference material was an uncontaminated soil of known characteristics, and was spiked with a diesel and mineral oil standard at a concentration equivalent to $16,000 \mathrm{mg} \mathrm{kg}^{-1}$. Relative standard deviation (RSD) values for all the soils was $<10 \%$. 


\subsection{Modified sequential extraction and pseudo-total element digestion}

Assessing metal partitioning through the non-specific sequential extraction with Chemometric Identification of Substrates and Element Distributions (CISED) can (1) limit the re-adsorption and re-distribution of elements among phases during extraction, often happening in genuine contaminated samples, (2) overcome problems linked with "operational speciation", where soil phases (operationally defined metal forms) are identified strictly based on their response to the extraction reagents, which not necessarily reflects the behaviour of natural samples (Adamo and Zampella, 2008).

In this work, a modified procedure for sequential extraction was conducted similar to that described in Cave et.al (2004). Soil samples of approximately $2 \mathrm{~g}$ were consecutively extracted by addition of $10 \mathrm{~mL}$ of an extraction solution (Table 3) which contained an increasing concentration of nitric acid (i.e. from 0 to $5 \mathrm{M}$ ). After adding $10 \mathrm{ml}$ of extraction solution, samples were mixed on an end-over-end shaker for 10 minutes, and the liquid phase was recovered via centrifugation (4350 $\mathrm{g}$ for $5 \mathrm{~min}$ ) and used for analysis; the soil pellet was resuspended again with the following extraction solution. Each extraction solution (7 solutions) was used twice to obtain a total of 14 extracts $(10 \mathrm{ml})$. As highlighted in Table 3, in the last 8 extractions $\left(\mathrm{E}_{7}\right.$ to $\mathrm{E}_{14}$ ) increasing amount of $\mathrm{H}_{2} \mathrm{O}_{2}$ were added to the extraction solutions to enhance degradation of organic matter and favour the dissociation of $\mathrm{Fe}-\mathrm{Mn}$ oxides (Filgueiras et al., 2002). However addition of $\mathrm{H}_{2} \mathrm{O}_{2}$ caused a high release of gas in the genuine contaminated soil samples, rendering the centrifugation and separation phase not possible without losing significant amount of soil material. We hypothesised that this was due to both (1) high calcium and phosphorus content typical of the content of cement-based stabilisers(Saeed, 2012),(2) the high reactive organic content soils caused by the presence of co-contamination (petroleum hydrocarbons), often observed in multi-contaminated soil matrix, such as the industrially-polluted soils used in this study. Therefore in our approach we 
implemented a modified version of the Cave et.al (2004) extraction procedure, which required the inclusion of an additional step. Hence, when $10 \mathrm{ml}$ of solution $4(9.75 \mathrm{ml}$ of 0.10 $\mathrm{M} \mathrm{HNO}_{3}$, and $0.25 \mathrm{ml}$ of $\mathrm{H}_{2} \mathrm{O}_{2} 100$ volumes $>30 \%$ w/v) were added to the samples, tubes were placed in a water bath for $30 \mathrm{~min}$ at $70^{\circ} \mathrm{C}$, to favour the reaction and limit the gas production. This additional step was sufficient to reduce the re-mixing of the solution allowing a proper separation when centrifuging.

The pseudo-total element digestion was performed according to the ISO 11047 method with aqua regia (ISO 11047:1998). Briefly, $0.5 \mathrm{~g}$ of soil was extracted with $8 \mathrm{~mL}$ hydrochloric/nitric acid mixture using a microwave digestion system. The extract was then filtered with $0.45 \mu \mathrm{m} 25 \mathrm{~mm}$ nylon syringe filters and made up to $50 \mathrm{~mL}$ volume with water. All pseudo-total and sequential solutions extracted were filtered with $0.45 \mu \mathrm{m} 25 \mathrm{~mm}$ nylon syringe filters and diluted 4 times with $1 \% \mathrm{HNO}_{3}$ before analysis by inductively coupled plasma mass spectrometry (ICP-MS A NexION® 350D ICP-MS, Perkin Elmer). The ICPMS was calibrated using a mixture of both major $(\mathrm{Ca}, \mathrm{Fe}, \mathrm{K}, \mathrm{Mg}, \mathrm{Mn}, \mathrm{Na}, \mathrm{S}, \mathrm{Si}, \mathrm{P})$ and trace (Al, As, Ba, Cd, Co, Cr, Cu, Hg, Li, Mo, Ni, Pb, Sb, Se, Sr, V, Zn) elements. The concertation ranges were $1,5,15,20,40 \mu \mathrm{g} / \mathrm{mL}$ for major elements and $0.01,0.1,0.5,1,2$ $\mu \mathrm{g} / \mathrm{mL}$ for trace elements. In both cases, working standards were prepared in matching sample matrix solutions (nitric acid 1\%). Calibration standards and samples extracts were spiked with the following mix of four internal standards: Sc, Ge, Rh, and Bi. ICP-MS was calibrated after each sample (14 sequential extracts). Limits of detection (LOD) were estimated as the concentrations corresponding to three times the standard deviation of measurements of analytes in a series of blank solutions (MilliQ water with $1 \% \mathrm{HNO}_{3}$ and buffer solution) $(n=40)$ treated the same way as the samples. The results are given in Table A 2. Additionally, acid blanks (1\% nitric acid), digestion blank, and guidance materials $\left(\mathrm{BGS}_{102}\right)$ were analysed every batch of 7 samples along with an adequate rinse time 
programmed in between samples; to monitor blank contamination, sensitivity, operating conditions, and extraction's accuracy. For the quantitative analyses, no blank correction was necessary as the calibration standards and samples were treated exactly in the same way adding the same amount and concentration of $\mathrm{HNO}_{3}$. The blank value was therefore taken into account in the calibration curve.

Mean repeatability of guidance materials $\left(\mathrm{BGS}_{102}\right)$ (expressed as relative standard deviation $\%$ ) was lower than 6 and $8 \%$ for sequential and aqua regia digestion respectively. All elements' concentrations have been converted into $\mathrm{mg} / \mathrm{kg}$ extracted from the soil-solid matrix. Descriptive statistics for the metals and metalloids concentrations (expressed in $\mathrm{mg} / \mathrm{kg}$ ) is presented in

\section{Table A1.}

Soil samples extraction recoveries obtained with the CISED method compared with pseudototal metal concentration averages were lower. The reason these extraction recoveries are not $100 \%$ is that the CISED extraction protocol mainly targets the easily soluble surface coatings without attacking the silicate matrix of soil. However, by assessing the pore-water, carbonates, and oxides fractions, it is sufficient to make assumption on HMs and metalloids fractionation as in contaminated soil the input of HMs (anthropogenic contamination) is mostly provided by non-silicate bound forms (Wuana et al., 2014).

\subsection{Modelling}

Data obtained from the HMs/metalloids sequential extraction were analysed using MatLab (Version R2015a) following the protocol developed by Cave et al. (2004). The non-specific sequential extraction method named Chemometric Identification of Substrates and Element Distributions (CISED) assumes that the chemical composition data for each extract is made up from different proportions of the physicochemical components in the soil. Since the 
algorithm is designed to identify the number of components based on principal component analysis and by Varimax rotation (Giacomino et al., 2011), for the purpose of the modelling, the soil samples extracted were grouped according to soil matrix type (Soil A, Soil B, Soil C, Soil D, and Soil E) and metals concentration (low, medium, and high contamination), in order to derive a more homogeneous data matrix for processing. Data processing of the sequential extraction was carried out on 5 multiple data matrices, each comprising the elemental extraction data ( 25 elements) for the 14 extracts for each test soil, over 7 conditions at 3 sampling times (294 rows of data per matrix). The data were processed using a selfmodelling mixture resolution (SMMR) algorithm in MatLab (Cave et al., 2004). The algorithm output is based on three main data matrixes: profile (PRF), distribution (DST), and composition (CMP). The PRF of each modelled soil component is calculated as the overall amount extracted $(\mathrm{mg} / \mathrm{kg})$ in each of the 14 extractions. The DST expressed in $\mathrm{mg} / \mathrm{kg}$ represents the concentration of each element across the different soil components identified by the model. The CMP data is expressed as a percentage of each element present in the identified component. Both PRF and CMP are then used to calculate the single element concentrations $(\mathrm{mg} / \mathrm{kg})$.

\subsection{Cluster analysis and complex associations between variables}

Modelled soil components and element distribution data, obtained from the MatLab algorithm, have been post-processed in RStudio to create a matrix, which has been further categorised using a clustering methodology, and visualised in a heatmap as previously described by Wragg et al., (2014) and Cox et al., (2013).

The SMMR algorithm produced distinct sets of physico-chemical phases for each of the 5 multiple data matrices analysed. Briefly, representative samples for each soil were selected and arranged in a data matrix containing on the left side the elements composition (CMP) (Na, Mg, Al, Si, P, S, K, Ca, V, Cr, Mn, Fe, Co, Ni, Cu, Zn, As, Li, Mo, Cd, Sb, Sr, Ba, Pb, 
Se) expressed as percentage, and on the right side the extraction profile (PRF) of each soil under investigation (expresses in $\mathrm{mg} / \mathrm{kg}$ ). The matrix was then imported in RStudio and subjected to hierarchical clustering where the data were mean centred and scaled with Euclidean distance and linkage using Ward's method (Ward, 1963) and the 'Agnes' function in the cluster package (Maechler et al. 2012) in RStudio (v.3.4.1). Clustering results were visualized using a heatmap (Figure 1) created using ggplot2, reshape2, grid, and ggdendro packages (Wickham 2007, Kahle and Wickham, 2013), where each row represents a physicochemical soil components found for a given soil. Soil name is indicated by the letter previously used in Table 1 (Soil A, Soil B, Soil C, Soil D, and Soil E), followed by the elements name (e.g $\mathrm{Ca}, \mathrm{Ca}-\mathrm{K}-\mathrm{Si}, \mathrm{Fe}-\mathrm{Mg}$ ) that make up $>10 \%$ of the physicochemical component composition. The hierarchal clustering obtained was used in parallel with chemical profile to provide interpretations and classify the components into common, distinct soil phases pore water (readily available or bioavailable), carbonates (potentially available with time) and oxides (bounded, non-available) and to assess the partitioning and bioavailable concentrations of HMs/metalloids in soil.

\subsection{Data analysis for descriptive statistics}

In the context of this research, PERMANOVA was used to investigate the significance and relationship between conditions tested (Cond 1, Cond 2, Cond 3, Cond 4, cond 5, Cond 6, and Cond 7), and TPHs concentration (high, medium, low) on (1) pore water, (2) exchangeable, and (3) non-exchangeable fractions of inorganic contaminants in the soil samples. Permutational Multivariate Analysis of Variance (PERMANOVA) is a Multivariate ANOVA with permutations, it was applied by using "adonis" function of the vegan library in R Studio (v.3.4.1, R) (Oksanen et al., 2011).

Descriptive statistics for the metals and metalloids concentrations in the different fractions and the 40 blank measurements and limit of detection (LOD) are provided in Tables A1-A3. 
To establish a direct or indirect correlation between HMs, which might be indicative of similar elements behaviour in multi-contaminated soil, univariate linear regression analysis was used by applying Pearson correlation coefficient with the "corrplot" package in R Studio (Oksanen et al., 2011). The output returned a correlation matrix for each soil (available in Appendix ; Tables A4 to A8) which allows assessment of relationships between HMs.

\section{Results and discussion}

\subsection{Soils characteristics and pseudo-total HMs and TPHs content}

All soil samples physicochemical properties, HMs/metalloids pseudo-total concentrations, and hydrocarbons total content are summarised in Table 4.

Soils A, B, and C are representative of industrial sites with low total nitrogen (700, 800 and $1200 \mathrm{mg} / \mathrm{kg}$ ) and phosphorus $(450,430$ and $500 \mathrm{mg} / \mathrm{kg}$ ) contents as well as alkaline $\mathrm{pH}$, conditions often found in urban settings (Vodyanitskii and Savichev, 2017). Soil samples collected at the treatment facility (Soil A, B, and C) belonged to a manufacturing gas plant, where often in addition to co-presence of PAHs and heavy metals, the coal ash and wood are generally characterised by alkaline $\mathrm{pH}$ (Hatheway and Speight, 2017). Soil B had high calcium and phosphorus content typical of the content of cement-based stabilisers (Saeed, 2012). For the majority of metals alkaline conditions can potentially increase the adsorption of HMs (Horváth et al., 2015), which reduces HM mobility and thus limits risk of exposure. However, some metals (Cr(VI), Mo(V)) and metalloids (e.g. As and Se) are mainly present in stable oxyanions forms (e.g. arsenate, selenite, vanadate, $\mathrm{Cr}(\mathrm{VI})$ chromate, and molybdate under alkaline $\mathrm{pH}$. Oxyanionic species are negatively charged and can be more mobile compared to the cationic species due to their high solubility and lack of adsorption on the surface of soil minerals (Cornelis et al., 2008). 
Soil D and Soil E texture was clay loam (sand content $<35 \%$ ), and $\mathrm{pH} 7.0-8.0$, and presented a higher nutrient content overall. In these soils the presence of soil particles smaller than $0.002 \mathrm{~mm}$, such as clay, could contribute to increase the HMs retention capacity due to the larger specific surface area (Ander et al., 2011).

The $\mathrm{C} / \mathrm{N}$ ratio of Soil $\mathrm{A}$ and $\mathrm{B}$ was more than 5 times higher than for the rural contaminated soils (Soil D and E), because of the larger amount of hydrocarbons present in the industrial contaminated soil. The high organic content might also be responsible for higher HMs retention, (Almeida et al., 2008; Millward et al., 2004). For all the soils investigated, the pseudo-total metal concentrations of $\mathrm{Pb}$ and $\mathrm{Zn}$ exceeded 8 times and 4 times the UK Soil Guideline Values (SGVs) and the European Directive 86/278/EEC; with an average pseudototal concentration of respectively $3400 \mathrm{mg} / \mathrm{kg}(\mathrm{Pb})$ and $2130 \mathrm{mg} / \mathrm{kg}(\mathrm{Zn})$ for the most contaminated sample (Soil C).

Descriptive statistics for the total concentration of aliphatic, PAHs, and TPHs compounds are provided in Table 4 where total maximum concentrations values in rural contaminated soil samples were half compared to industrial samples; 500, 180, 460, 430, $260 \mathrm{mg} / \mathrm{kg}$ ALKs, 2700, 1100, 244, 400, $360 \mathrm{mg} / \mathrm{kg}$ PAHs, for Soil A, Soil B, Soil C, Soil D and Soil E, respectively.

\subsection{HMs Solid phase distribution}

Soil samples were subjected to the CISED sequential extraction procedure to determine the physicochemical soil components (substrates) being extracted from the soil (e.g carbonates, clays, exchangeable phases); and the solid phase distribution of HMs/metalloids between each identified soil component. Figure 1 indicates the presence of 10 distinct physicochemical clusters (blocks) which have been further grouped as: (1) Pore water, (2) Carbonates (low and high carbonates) and (3) oxides (Al-oxides, Mn-Oxides, and Fe-oxides) (Figure 2). HMs chemical speciation results, obtained by sequential extraction, are essential 
to understand their mobility; the results obtained show that the extractable amounts obtained from each fraction can vary widely (Figure 1 and Figure 2). The first physicochemical cluster (Figure 1, clusters 3, 5, and 8) is dominated by the presence of $\mathrm{Na}, \mathrm{Ca}, \mathrm{S}$, and $\mathrm{K}$, and was extracted by the initial step of CISED, when deionized water $\left(E_{1}-E_{2}\right)$ or low acid concentration $\left(\mathrm{HNO}_{3} 0.01 \mathrm{M}, \mathrm{E}_{3}-\mathrm{E}_{4}\right)$ was used. This step was used to extract elements that are soluble, highly mobile, and most likely associated with the pore water fraction. The second physicochemical cluster, Ca dominated, is well identified in these samples (in particular Soil B) and mainly composed of $\mathrm{Ca}$ and, to lesser extent, of K, Si, and S (Figure 1, clusters 1, 2, 7, and 9). The elevated presence of $\mathrm{Ca}$ in this fraction is linked to the fact that common binders are calcium-based. This fraction can be divided into low carbonate (extracted with low acid strength $\mathrm{HNO}_{3} 0.05-0.1 \mathrm{M}, \mathrm{E}_{5}-\mathrm{E}_{6}, \mathrm{E}_{7}-\mathrm{E}_{8}$ ) and high carbonate (extracted with $\mathrm{HNO}_{3} 0.5 \mathrm{M}$, $\left.\mathrm{E}_{9}-\mathrm{E}_{10}\right)$. The third physicochemical cluster identified through the modelling corresponds to oxides including Mn-oxides, Al-oxides, and Fe-oxides (Figure 1, clusters 4, 6, and 10). This cluster was associated with elements (e.g. $\mathrm{Mn}, \mathrm{Al}$, and Fe) released after $\mathrm{H}_{2} \mathrm{O}_{2}$ addition and dissolved by the concentrated $\mathrm{HNO}_{3}\left(\mathrm{E}_{7}\right.$ to $\left.\mathrm{E}_{14}\right)$. These elements were extracted with very strong acid concentrations $\left(\mathrm{E}_{9}-\mathrm{E}_{14}\right)$ and likely associated with the clay components of the soil, therefore being overall immobile under natural environmental conditions.

\subsection{Relationship between HMs and metalloids distribution and bioavailability}

The compositional data and distribution of HMs and metalloids, for all soil samples in these fractions, were obtained by transforming each original raw concentration (i.e. $\mathrm{mg} / \mathrm{kg}$ ) into proportions of the total $(100 \%)$ and are shown in Figure 2. Concentrations have been averaged across time and conditions in order to provide an overview of the overall metal behaviour in the five soils types (soil A, soil B, soil C, soil D, and soil E) (see for details Table A3). The most mobilised elements in the exchangeable fraction were the following: $\mathrm{Hg}$ and Se for Soil A; Cd and Se for Soil B; Cd and $\mathrm{Hg}$ for Soil C; Cd for Soil D, and Cd, Cu for 
Soil E. Conversely, As and Cr showed the least mobility. The order of mobility of the metals in the exchangeable fraction was as follows: $\mathrm{Hg}>\mathrm{Se}>\mathrm{Ni}>\mathrm{Cr}>\mathrm{Cd}>\mathrm{As}>\mathrm{Zn}>\mathrm{Cu}>\mathrm{Pb}$ (Soil A); $\mathrm{Se}>\mathrm{Cd}>\mathrm{Cr} \mathrm{Hg}>\mathrm{Ni}>\mathrm{As}>\mathrm{Cu}>\mathrm{Zn}>\mathrm{Pb}($ Soil B); $\mathrm{Cd}-\mathrm{Hg}-\mathrm{Zn}>\mathrm{Pb}>\mathrm{Ni}>\mathrm{Cu}>$ $\mathrm{Se}>\mathrm{Cr}>\mathrm{As}($ Soil $\mathrm{C}) ; \mathrm{Cd}>\mathrm{Hg}>\mathrm{Ni}-\mathrm{Zn}>\mathrm{Cu}>\mathrm{As}>\mathrm{Se}>\mathrm{Pb}>\mathrm{Cr}($ Soil $\mathrm{D})$; and $\mathrm{Cd}>\mathrm{Cu}>$ $\mathrm{Pb}-\mathrm{Se}>\mathrm{Zn}>\mathrm{Ni}>\mathrm{As}>\mathrm{Cr}>\mathrm{Hg}$ (Soil E). Interestingly As was the least mobile, while $\mathrm{Cd}$ was very mobile at $\mathrm{pH}>9$ in the industrial soil samples (Soil A, Soil B, and Soil C). Previous literature showed that As adsorption tend to decrease under alkaline conditions $(\mathrm{pH}>9)$ due to the presence of negatively charged $\mathrm{H}_{2} \mathrm{AsO}_{3}, \mathrm{HAsO} 3$, and $\mathrm{AsO}_{3}$ (forming soluble species of As(III)) (Dias et al., 2009). However in these samples, As was found mostly associated with the non-exchangeable fraction ( $\mathrm{Mn}-\mathrm{Al}$ and Fe oxides). Therefore we can assume that the majority of As was present as inorganic oxyanion $\mathrm{As}(\mathrm{V})$ forming $\mathrm{H}_{2} \mathrm{AsO}_{4}$ and $\mathrm{HAsO}_{4}{ }^{2-}$, which is known to strongly interact with oxides (positively charged) in both un-contaminated and contaminated soils (Lin and Puls, 2000; Sarkar, 2002).

In soil $\mathrm{C}, \mathrm{D}$, and $\mathrm{E}$ samples, $\mathrm{Cd}$ sorption was limited as the element was predominantly found in the exchangeable fraction which is likely due to the influence of the soil-solid particle distribution on $\mathrm{Cd}$ behaviour. Previous studies highlighted that $\mathrm{Cd}$ binding on clay minerals is weaker compared to binding to organic matter (Janssen, 1997; Prokop et al., 2003) which was the case for these soils.

In Soil A, both $\mathrm{Mn}$ and $\mathrm{Fe}$ were below detection limit in the pore water fraction. Changes in $\mathrm{Mn}$ and Fe concentrations in the pore water was negligible for Soil B and Soil C. In contrast for Soil E, both Fe and Mn concentrations decreased overtime in the pore water, suggesting that pore water $\mathrm{Fe}(\mathrm{II})$ was oxidised to insoluble $\mathrm{Fe}(\mathrm{III})$.

The partitioning, mobility and distribution of HMs and metalloids assessed in these soil samples can provide different level of information, such as (i) information on the origin of the 
contamination, (ii) the effectiveness of cement-stabiliser and potential reuse of soil material, (iii) the limitation often associated with guideline values thresholds. HMs/metalloids partitioning can provide information on the origin of the contamination, where often HMs from anthropogenic sources usually bind to the exchangeable fractions (Frentiu et al., 2008; Hu et al., 2006; Iwegbue, 2015); as observed for Soil A where 90, 50, and 25\% of $\mathrm{Hg}$,Se and Ni were distributed in the exchangeable fraction. Over 33,28 , and $20 \%$ of $\mathrm{Se}, \mathrm{Cd}$, and $\mathrm{Cr}$ (Soil B), and over $80 \%$ of $\mathrm{Cd}, \mathrm{Hg}, \mathrm{Pb}$, and $\mathrm{Zn}$ (Soil C) were found in the exchangeable fraction; while Soil D, E showed lower values below 50\% for $\mathrm{Zn}$ and Ni. Nevertheless, HMs and metalloids present in the exchangeable fraction can also become mobilised over time (Baran and Tarnawski, 2015) and should therefore be considered for a more complete assessment of the entire pool of mobilisable elements. However data regarding the soil origin and underline geology must also be considered in order to estimate the weight of the effect of geogenic or (anthropogenic) contribution on HMs/metalloids bioavailability (Borgese et al., 2013). Being the soil samples provided anonymously from a treatment facility, no further information on the geology, location, or origins of the contamination were provided. The potential of re-using soil that has been treated or remediated is a viable and sustainable strategy (Mehta et al., 2018), however concerns regarding safety of the re-used material and the possible further spreading of contaminants still exists. Results obtained from sequential extraction highlighted that even though Soil A, and B showed a similar HMs mobility pattern, where some of the less mobile elements including $\mathrm{Cr}$, As, and $\mathrm{Zn}$ were significantly more associated with the non-exchangeable fraction of Soil B (treated with stabiliser). The presence of the cement stabiliser was able to reduce HMs solubility, adsorption, and incorporation to the porous surfaces, as previously observed in the literature (Jiang et al., 2006; Johnson, 2004). Since no information was available on the type of cement stabiliser used in Soil B, it was not possible to draw further conclusion on the mechanism dominating 
the fixation of HMs. Ultimately, whilst providing information on the target HMs metalloids for risk assessment, total concentration cannot provide sufficient information about elements mobility and bioavailability in soil; highlighting that soil guideline values (SGVs) are useful, but their application in the detailed quantitative risk assessment is limited. Sequential extraction instead provided specific information on the solid-phase fractionation of HMs/metalloids in soil (Cox et al., 2013; Palumbo-Roe et al., 2013; Reis et al., 2014), therefore allowing relevant stakeholders and regulators to make informed assumptions on bioavailability for risk assessment (Kaakinen et al., 2015).

\subsection{Behaviour of exchangeable metal fraction over time}

Average HMs/metalloids content and distribution across the three fractions (pore water, exchangeable, and non-exchangeable) in the five soil samples for the 7 conditions tested are presented in Figure 3. In Soil $\mathrm{A}$, no changes were found for $\mathrm{Cd}, \mathrm{Cr}, \mathrm{Cu}, \mathrm{Ni}, \mathrm{Pb}$, and $\mathrm{Zn}$ over time. On the other hand, As and Se concentrations changes can be explained by the good AsSe-metals correlation (Tables A4 to A6) suggesting that As, Se and metals could come from sulphides. The mobility and toxicity of As and Se depends on their redox state. In neutral to alkaline soils, As and Se mobility increases because of the formation of arsenate $\left(\mathrm{H}_{2} \mathrm{AsO}_{4}{ }^{-}\right)$ and selenate $\left(\mathrm{SeO}_{4}{ }^{-2}\right)$ ions (Soukup, 2013), which weakly bond to oxides and other minerals. For Soil B, all the HMs/metalloids showed little or no difference in distribution across the three sampling events (T0, T6, and T12). Most of HMs/metalloids were almost entirely found in the non-exchangeable fraction. Such behaviour can be explained because either (1) the addition of the stabilisers was effective in retaining the contamination over time, as highlighted in previous paragraph, or (2) these metals were mainly associated with clay related elements (e.g. $\mathrm{Mn}, \mathrm{Al}$, and $\mathrm{Fe}$ ) released after $\mathrm{H}_{2} \mathrm{O}_{2}$ addition and dissolved by the concentrated $\mathrm{HNO}_{3}$. This suggests that $\mathrm{Pb}, \mathrm{Cu}$, and $\mathrm{Zn}$ are unlikely to become available with time. For example, $\mathrm{Pb}$ quantities present in the exchangeable fraction (Soil B) fell within the 
range of the median concentration for UK urban topsoil G-BASE data $(48-128 \mathrm{mg} / \mathrm{kg})$, with a 75th percentile of $253 \mathrm{mg} / \mathrm{kg}$ (Ander et al., 2011) (Table A3).

Similarly, As, Cd, Cr, and Zn in Soil B were not affected by ageing. In particular As (93\%) and $\mathrm{Cr}(81 \%)$ were almost exclusively present in the non-exchangeable fraction. $\mathrm{Pb}, \mathrm{Cu}, \mathrm{Ni}$, and Se distributions barely changed overtime being exclusively in the exchangeable fraction. Even though $\mathrm{Pb}$ is one of the main contaminant of concern with high concentration in exchangeable fraction (mean $1500 \mathrm{mg} / \mathrm{kg}$ ), its concentration persisted over the 12 -month incubation. This is probably due to the formation of insoluble $\mathrm{Pb}$ compounds such as phosphates, carbonates, and oxides typically formed when the $\mathrm{pH}$ is above 6 (Wuana and Okieimen, 2011). Zn was almost entirely associated with the exchangeable fraction: it is well known to generally display strong affinity to the non-residual fraction of the soil (Naji et al., 2010).

Soil $\mathrm{D}$ and $\mathrm{E}$ presented a very similar distribution with the exception of $\mathrm{Cu}, \mathrm{Hg}, \mathrm{Pb}$, and $\mathrm{Se}$, which were more exchangeable in Soil E. In both soils and similarly to Soil B, As, Cd, Cr, $\mathrm{Cu}, \mathrm{Pb}$, and $\mathrm{Se}$ were not affected by ageing. The increase of $\mathrm{Zn}$ concentration in the exchangeable fraction observed for Soils $\mathrm{D}$ and $\mathrm{E}$ during mesocosms incubation was attributed to $\mathrm{Zn}$ affinity for hydroxides and carbonates, which can promote remobilization of this element in soil (Kumar, 2016). Ni also showed trends similar to $\mathrm{Zn}$ in metal release and its concertation increased in mobile fraction after incubation.

Ageing, has been previously identified as a main driver for leachability of metals in soil. However, an inverse relationship between time of residence in soil and amount of metal leachable exists: the shorter the time, the larger is the amount that can be released (Kumar, 2016). Regarding the time when the contamination occurred, there was no information associated to the soil samples collected. Nevertheless, it was assumed that contamination in Soils D and E was more recent when compared to Soils A, B, and C. 


\subsection{Influence of the environmental parameters on HMs and metalloids behaviour and fate}

Sequentially extracted fractions were compared to gain a mechanistic understanding on how measurements varied when different conditions were applied at the different times. After evaluating the concentration and distribution of the HMs/metalloids in the 5 soils, a detailed investigation of the 3 metal pool fractions behaviour under the 7 mesocosms conditions was carried out. No significant differences were found for the same soil samples exposed to different $\mathrm{pH}$ (Conds 1 and 2), different moisture content (Conds 3 and 4) and different temperature (Conds 6 and 7) (data not shown).

PERMANOVA was used to investigate the significance and relationship between conditions tested (Cond 1-7), and TPHs concentration (high, medium, low), on (1) pore water, (2) exchangeable, and (3) non-exchangeable fractions of inorganic contaminants in the soil samples. For all industrial contaminated samples (Soil A, Soil B, and Soil C) no significant effect $(p>0.5)$ of conditions, nor TPHs concentrations on pore water, exchangeable, and non-exchangeable fractions were recorded. This confirms that difference observed in HMs partitioning among different fractions, in different soil samples was minimal, and that these soil materials potentially pose low risk to the environment. For both Soil D and E no significant effect $(p>0.5)$ of conditions, TPHs concentrations on pore water concentrations was observed. However, in Soil D only, a significant effect of TPHs concentrations on exchangeable ( $p=0.001)$ and non exchangeable $(p=0.003)$, fractions were found; suggesting that additional factors may play a role in contaminant concentration changes (e.g degradation of organic contaminants, volatilisation, and interaction with soil organic matter), rather than the condition applied, which did not cause a significant difference between groups. The copresence of TPHs increased the HMs/ metalloids redistribution into the exchangeable fraction for $\mathrm{Zn}, \mathrm{Pb}, \mathrm{Ni}, \mathrm{As}$, and $\mathrm{Cu}$, while no changes were observed for $\mathrm{Ce}, \mathrm{Cr}, \mathrm{Hg}$, and $\mathrm{Se}$. 
While individual compounds in a complex chemical mixture are assumed to have independent sorption behaviour, at high concentrations co-presence of contaminants can influence sorption as a results of changes in the soil-solution equilibrium (Gao et al., 2006). Thus, co-presence of mixed contaminants such as petroleum hydrocarbons and heavy metals may influence/change mobility, behaviour and bioavailability of HMs. The degree and type of combined effect obtained from mixtures is highly dependent on both concentration and time of persistence in soil (Wuana and Okieimen, 2011). Most studies report a negative effect of PAHs-HMs co-occurrence, due to the negative influence of HMs on soil microbial community which can hamper the biodegradation. However some other studies highlighted the positive interaction of heavy metals and PAHs; Saison et al. (2004), Gao et al. (2006), and Zhang et al. (2011) observed an increase in adsorption of phenanthrene in presence of HMs, additionally a positive interaction between $\mathrm{Zn}, \mathrm{Cd}$, and phenanthrene towards microbial enzyme activity was observed in Shen et al (2005) study. Some examples of studies assessing effects of co-contamination are present in literature (Ding et al., 2017; Iwegbue, 2015; Lin et al., 2008), however mechanisms that regulates sequestration, displacement, and partitioning of HMs in complex contaminated sites is still poorly understood.

Since $\mathrm{pH}$ governs trace metal solubility (low $\mathrm{pH}$ decreases sorption and increases bioavailability and mobility), a greater variation in $\mathrm{HMs} /$ metalloids distribution associated to Conds 1 and 2 were expected: this was not observed in any of the soils tested. Different authors have previously reported that $\mathrm{pH}$ has less or no effect on $\mathrm{Cu}, \mathrm{Pb}$ and $\mathrm{Zn}$ sorption (De Matos et al., 2001; Gomes et al., 2001; Katyal and Sharma, 1991). Such behaviour suggests that soil chemical properties (e.g. pH) are not the only parameters affecting HMs remobilisation. This finding can be attributed to the addition of mild acidic sulfuric acid solutions (Conds 1 and 2) which were not sufficient to permanently modify the soils' $\mathrm{pH}$. This acid addition could just cause a transient decrease in $\mathrm{pH}$ and thus revealed the strong $\mathrm{pH}$ 
buffer capacity of these soils. Our finding were consistent to previous results in the literature which highlighted the minor effect on HMs leaching behaviour affected by mildly acidic and neutral pH soil values (Du et al., 2014). The lack of changes in the HMs stability was more remarkable in samples with higher sorption capacity owing to the presence of porous material such as high clay content (Soil D) or presence of cement stabiliser (Soil B), which could have played a role in increasing the retention of soluble HMs. A higher interstitial water (Cond 4) can cause a decrease in soil redox potential and change HMs oxidation states (Mukwaturi and Lin, 2015). This influences the fate and transport of metals and, combined with $\mathrm{pH}$, could also control solubility or the formation of coordination complexes. Changes in $\mathrm{pH}$ and moisture content (Conds 3 and 4) did not affect however, the behaviour and transformation pathways of the metals in the soils tested. Among the factors that could influence metal distribution, temperature (Conds 6 and 7) has previously been found not to exert any measurable effects on $\mathrm{Pb}$ solubility (Kalbasi et al., 1978) or Cd leaching (Basta and Tabatabai, 1992). A similar trend was observed for moisture on paddy soil (Liu et al., 2016).

\subsection{Descriptive statistics}

Descriptive statistics were conducted on the data to identify relationships between HMs and metalloids, details are provided in Appendix . A positive correlation coefficient among HMs suggests that those elements may share common sources, mutual dependence, and have identical behaviour during the transport (Kennou et al., 2015; Suresh et al., 2012, 2011). Information on potential sources and pathways of HMs can be obtained based on interelement relationships (Altan et al., 2016).

$\mathrm{Zn}, \mathrm{As}, \mathrm{Cd}$ and $\mathrm{Pb}$ were positively correlated for Soil $\mathrm{A}$, whereas $\mathrm{Cu}$ did not relate with any of the studied metals and Se was only correlated with $\mathrm{Hg}$ (Table A4). Similarly, a significant 
positive correlation was also detected between $\mathrm{Zn}, \mathrm{As}, \mathrm{Cd}, \mathrm{Pb}$ and $\mathrm{Se}$ for Soil B (Table A5).

In Soil C, a significant positive correlation was also observed for $\mathrm{Zn}, \mathrm{Cd}$ and $\mathrm{Pb}$ (Table A6). 
Table A7 and Table A8 further showed high Pearson's correlation coefficients between $\mathrm{Cu}$, $\mathrm{Zn}, \mathrm{As}, \mathrm{Pb}$, and Se in Soil $\mathrm{D}$ and between $\mathrm{Ni}, \mathrm{Cu}, \mathrm{Zn}, \mathrm{Cd}, \mathrm{Pb}$, and $\mathrm{Se}$ in Soil E.

$\mathrm{Cu}, \mathrm{Zn}$, and $\mathrm{Cd}$ in particular belong to the groups 12 and 13 of the periodic table and share similar physico-chemical characteristics therefore behaving similarly. Absence of correlation between $\mathrm{Hg}-\mathrm{Cu}(-0.052)$ or $\mathrm{Pb}-\mathrm{Hg}(-0.080)$ for Soil A, Cr-Hg (0.304) Soil B, Ni-Cr (0.436), $\mathrm{Pb}-\mathrm{Hg}(0.273)$ for Soil C, Cd-Cr (-0.296), Cd-As (-0.270) for Soil D, and Cr-Hg (-0.067), Cu$\mathrm{Cr}(0.125)$ for Soil E suggests that these metals behave very differently and their fate and distribution are not controlled by a single common factor (Kennou et al., 2015).

\section{Conclusions}

Assessing the partitioning of HMs and metalloids in soil is a more suitable tool to understand distribution and fate, rather than total concentration and the generic guideline values which commonly assumes that $100 \%$ of the contaminant of concern is bioavailable. The solid phase distribution highlighted the following: (1) while pseudo-total concentration shows that $\mathrm{Pb}$, $\mathrm{Cu}$, and $\mathrm{Zn}$ exceed the guideline values, only a negligible fraction of these HMs were dissolved in pore water, which confirm that these metals were not readily-available;(2) the concentration of $\mathrm{Zn}$ and $\mathrm{Pb}$ in the mobile fractions (exchangeable) was higher than those in the non-mobile fraction (non-exchangeable), both fractions remained stable during weathering and under the different treatment applied; (3) a clear difference was observed between Soil A and Soil B, where HMs were significantly more bounded in Soil B, a fact confirming that the stabilisation was a successful technique to minimize element's mobility. We assessed the behaviour of exchangeable metal fraction over time, results showed that HMs were stable and, similar behaviours were observed for both industrial contaminated soils (Soil A, B and C), and rural contaminated soil (Soil C and E) at 0, 6 and 12 months. In addition, the conditions applied such as different $\mathrm{pH}$ (Cond 1 and Cond 2), different moisture 
(Cond 3 and Cond 4) and temperature (Cond 6 and Cond 7) did not have a clear pattern/effect on metals concentration over time. This finding can be attributed to both the soils having a strong soil $\mathrm{pH}$ buffer capacity, and the initial alkaline $\mathrm{pH}$ of the soil samples. Lastly, the Pearson's correlation coefficients showed similarities between investigated HMs/metalloids and their observed distribution pattern among the three phases (pore water, exchangeable, and non-exchangeable), and helped to classify these HMs in groups. Overall, the limited changes in metal fractionation in these soil samples, including limited removal from more recalcitrant fractions, suggest that stable soil-complexes and interaction with the soil matrix were formed and may render the elements less mobile over time, therefore reducing environmental risk. In conclusion, standard guidelines values can provide initial information on the target HMs for risk assessment, but they are not sufficient to understand the role of metal speciation and soil properties on metal bioavailability and their potential effects (risk). Using sequential extraction to measure the HMs concentration allows site specific assessment criteria to be determined and refined, providing a better estimate of the HMs/ metalloids potential bioavailable concentration.

Acknowledgements: This work was completed as part of the REMEDIATE (Improved decision-making in contaminated land site investigation and risk assessment) Marie-Curie Innovation Training Network (Grant agreement No. 643087). The authors also thank Dr Mark Cave (British Geological Survey) for his support with the chemometric identification of substrates and element distributions. 


\section{References}

Adamo, P., Zampella, M., 2008. Chemical speciation to assess potentially toxic metals' (PTMS') bioavailability and geochemical forms in polluted soils. In: BELKIN, H.E., LIMA, A.B.T.-E.G. (Eds.), . Elsevier, Amsterdam, pp. 175-212.

Adedigba, B.M., Semple, K.T., 2015. Bioavailability of Persistent Organic Pollutants in Soils: Concept, Analytical Tools, and Application in the Risk Assessment. In: Zeng, E.Y.B.T.-C.A.C. (Ed.), Persistent Organic Pollutants (POPs): Analytical Techniques, Environmental Fate and Biological Effects. Elsevier, pp. 493-512.

Agbenin, J.O., Welp, G., 2012. Bioavailability of copper, cadmium, zinc, and lead in tropical savanna soils assessed by diffusive gradient in thin films (DGT) and ion exchange resin membranes. Environ. Monit. Assess. 184, 2275-2284.

Almeida, C.M.R., Mucha, A.P., Delgado, M.F.C., Isabel Caçador, M., Bordalo, A.A., Vasconcelos, M.T.S.D., 2008. Can PAHs influence Cu accumulation by salt marsh plants? Mar. Environ. Res. 66, $311-318$.

Altan, M., Ayyildiz, Ö., Malkoç, S., Yazici, B., Koparal, S., 2016. Heavy Metal Distribution Map in Soil by Using GIS Techniques Heavy Metal Distribution Map in Soil by Using GIS Techniques 5, 14-20.

Alvarez, M.B., Domini, C.E., Garrido, M., Lista, A.G., Fernández-Band, B.S., 2011. Single-step chemical extraction procedures and chemometrics for assessment of heavy metal behaviour in sediment samples from the Bahía Blanca estuary, Argentina. J. Soils Sediments 11, 657-666.

Ander, E., Cave, M.R., Johnson, C.C., Palumbo-Roe, B., 2011. Normal background concentrations of contaminants in the soils of England. Available data and data exploration. Br. Geol. Surv. Comm. Rep. CR/11/145, 124pp.

Ashraf, M.A., Maah, M.J., Yusoff, I., 2012. Chemical Speciation and Potential Mobility of Heavy Metals in the Soil of Former Tin Mining Catchment. Sci. World J. 2012, 1-11.

Baran, A., Tarnawski, M., 2015. Assessment of heavy metals mobility and toxicity in contaminated sediments by sequential extraction and a battery of bioassays. Ecotoxicology 24, 1279-1293. 
Basta, N.T., Tabatabai, M.A., 1992. Effect of cropping systems on adsorption of metals by soils: ii. Effect of pH. Soil Sci. 153.

Bermond, A.P., 1992. Thermodynamics applied to the study of the limits of sequential extraction procedures used for the speciation of trace elements in sediments and soils. Environ. Technol. (United Kingdom) 13, 1175-1179.

BS EN 13654-2:2001. Soil improvers and growing media. Determination of nitrogen. Dumas method. Bolan, N., Kunhikrishnan, A., Thangarajan, R., Kumpiene, J., Park, J., Makino, T., Kirkham, M.B., Scheckel, K., 2014. Remediation of heavy metal(loid)s contaminated soils - To mobilize or to immobilize? J. Hazard. Mater. 266, 141-166.

Borgese, L., Federici, S., Zacco, A., Gianoncelli, A., Rizzo, L., Smith, D.R., Donna, F., Lucchini, R., Depero, L.E., Bontempi, E., 2013. Metal Fractionation in Soils and Assessment of Enviromental Contamination in the Vallecamonica, Italy. Environ. Sci. Pollut. Res. Int. 20, 5067-5075.

Caporale, A.G., Violante, A., 2016. Chemical Processes Affecting the Mobility of Heavy Metals and Metalloids in Soil Environments 15-27.

Cave, M.R., Milodowski, A.E., Friel, E.N., 2004. Evaluation of a method for identification of host physico-chemical phases for trace metals and measurement of their solid-phase partitioning in soil samples by nitric acid extraction and chemometric mixture resolution. Geochemistry Explor. Environ. Anal. 4, 71-86.

Chang, Y.T., Hseu, Z.Y., Zehetner, F., 2014. Evaluation of phytoavailability of heavy metals to Chinese cabbage (Brassica chinensis L.) in rural soils. Sci. World J. 2014.

Cipullo, S., Prpich, G., Campo, P., Coulon, F., 2018. Assessing bioavailability of complex chemical mixtures in contaminated soils: Progress made and research needs. Sci. Total Environ. 615, 708723.

Cornelis, G., Johnson, C.A., Gerven, T. Van, Vandecasteele, C., 2008. Leaching mechanisms of oxyanionic metalloid and metal species in alkaline solid wastes: A review. Appl. Geochemistry 23, 955-976. 
Cox, S.F., Chelliah, M.C.M., McKinley, J.M., Palmer, S., Ofterdinger, U., Young, M.E., Cave, M.R., Wragg, J., 2013. The importance of solid-phase distribution on the oral bioaccessibility of $\mathrm{Ni}$ and $\mathrm{Cr}$ in soils overlying Palaeogene basalt lavas, Northern Ireland. Environ. Geochem. Health 35, 553567.

Cui, Y., Zhu, Y.-G., Zhai, R., Huang, Y., Qiu, Y., Liang, J., 2005. Exposure to metal mixtures and human health impacts in a contaminated area in Nanning, China. Environ. Int. 31, 784-790.

De Matos, A.T., Fontes, M.P.F., Da Costa, L.M., Martinez, M.A., 2001. Mobility of heavy metals as related to soil chemical and mineralogical characteristics of Brazilian soils. Environ. Pollut. 111, $429-435$.

Dean, J.R.R., Scott, W.C.C., 2004. Recent developments in assessing the bioavailability of persistent organic pollutants in the environment. TrAC - Trends Anal. Chem. 23, 609-618.

Di Bonito, M., Breward, N., Crout, N., Smith, B., Young, S.D., Zhang, H., 2018. Chapter 10 - Extraction and Characterization of Pore Water in Contaminated Soils A2 - Vivo, Benedetto De. In: Belkin, H.E., Lima, A.B.T.-E.G. (Second E. (Eds.), . Elsevier, pp. 195-235.

Dias, F.F., Allen, H.E., Guimarães, J.R., Taddei, M.H.T., Nascimento, M.R., Guilherme, L.R.G., 2009. Environmental behavior of arsenic(III) and (V) in soils. J. Environ. Monit. 11, 1412-1420.

Ding, Q., Huang, X., Hu, H., Hong, M., Zhang, D., Wang, K., 2017. Impact of pyrene and cadmium cocontamination on prokaryotic community in coastal sediment microcosms. Chemosphere 188,320 328.

Du, Y.-J., Wei, M.-L., Reddy, K.R., Liu, Z.-P., Jin, F., 2014. Effect of acid rain pH on leaching behavior of cement stabilized lead-contaminated soil. J. Hazard. Mater. 271, 131-140.

Fernández-Ondoño, E., Bacchetta, G., Lallena, A.M., Navarro, F.B., Ortiz, I., Jiménez, M.N., 2017. Use of BCR sequential extraction procedures for soils and plant metal transfer predictions in contaminated mine tailings in Sardinia. J. Geochemical Explor. 172, 133-141.

Filgueiras, A. V., Lavilla, I., Bendicho, C., 2002. Chemical sequential extraction for metal partitioning in environmental solid samples. J. Environ. Monit. 4, 823-857. 
Frentiu, T., Ponta, M., Levei, E., Gheorghiu, E., Benea, M., Cordos, E., 2008. Preliminary study on heavy metals contamination of soil using solid phase speciation and the influence on groundwater in Bozanta-Baia Mare Area, Romania. Chem. Speciat. Bioavailab. 20, 99-109.

Gao, Y., Xiong, W., Ling, W., Xu, J., 2006. Sorption of phenanthrene by soils contaminated with heavy metals $65,1355-1361$.

Ge, Y., Sauvé, S., Hendershot, W.H., 2005. Equilibrium Speciation of Cadmium, Copper, and Lead in Soil Solutions. Commun. Soil Sci. Plant Anal. 36, 1537-1556.

Giacomino, A., Abollino, O., Malandrino, M., Mentasti, E., 2011. The role of chemometrics in single and sequential extraction assays: A Review. Part II. Cluster analysis, multiple linear regression, mixture resolution, experimental design and other techniques. Anal. Chim. Acta 688, 122-139.

Gomes, P.C., Fontes, M.P.F., da Silva, A.G., de S. Mendonça, E., Netto, A.R., 2001. Selectivity Sequence and Competitive Adsorption of Heavy Metals by Brazilian Soils. Soil Sci. Soc. Am. J. 65, 1115.

Grosjean, P.;, Ibanez, F., Etienne, M.;, 2018. Package ' pastecs .'

Harmsen, J., Naidu, R., 2013. Bioavailability as a tool in site management. J. Hazard. Mater. 261, 840846.

Hatheway, A.W., Speight, T.B., 2017. Manufactured Gas Plant Remediation: A Case Study. CRC Press. Hodson, M.E., Vijver, M.G., Peijnenburg, W.J.G.M., 2011. Bioavailability in soils. Deal. with Contam. Sites From Theory Towar. Pract. Appl. 721-747.

Horváth, A., Szűcs, P., Bidló, A., 2015. Soil condition and pollution in urban soils: evaluation of the soil quality in a Hungarian town. J. Soils Sediments 15, 1825-1835.

Hu, N., Li, Z., Huang, P., Tao, C., 2006. Distribution and mobility of metals in agricultural soils near a copper smelter in South China. Environ. Geochem. Health 28, 19-26.

Islam, M.S., Ahmed, M.K., Habibullah-Al-Mamun, M., 2015. Metal speciation in soil and health risk due to vegetables consumption in Bangladesh. Environ. Monit. Assess. 187.

ISO 10390:2005 Soil quality -- Determination of $\mathrm{pH}, 7 \mathrm{pp}$ available at https://www.iso.org/standard/40879.html 
ISO 11263:1994. Soil quality -- Determination of phosphorus -- Spectrometric determination of phosphorus soluble in sodium hydrogen carbonate solution. available at https://www.iso.org/standard/19241.html

ISO 11274:1998 Soil quality -- Determination of the water-retention characteristic -- Laboratory methods, $20 \mathrm{p}$ available at https://www.iso.org/standard/19252.htm

ISO 11277:2009. Soil quality -- Determination of particle size distribution in mineral soil material Method by sieving and sedimentation. https://www.iso.org/standard/54151.html

Iwegbue, C.M.A., 2011 Assessment of Heavy Metal Speciation in Soils Impacted With Crude Oil in the Niger Delta, Nigeria, Chemical Speciation and Bioavailability. 23, 2011, 7-15.

Janssen, R.P.T., 1997. Equilibrium partitioning of heavy metals in dutch field soils 2. Prediction of metal accumulation in ews. Environ. Toxicol. Chem. 16, 2479-2488.

Jiang, J.G., Xu, X., Zhang, Y., 2006. Investigation of leaching characteristics of heavy metals during cement stabilization of fly ash from municipal solid waste incinerator. Huan Jing Ke Xue 27, 2564 2569.

Johnson, C.A., 2004. Cement stabilization of heavy-metal-containing wastes. Geol. Soc. London, Spec. Publ. 236, 595 LP-606.

Kaakinen, J., Kuokkanen, T., Leskinen, H., Välimäki, I., Kujala, K., 2015. The use of a four-stage sequential leaching procedure and the corresponding one-phase extractions for risk assessment of potential harmful substances in waste rock utilized in railway ballast. Chem. Speciat. Bioavailab. 27, $71-80$.

Kahle D. and Wickham H. (2013). “ggmap: Spatial Visualization with ggplot2”. In: The R Journal 5 (1), pp. 144-162. url: http://journal.r-project.org/archive/2013-1/kahle-wickham.pdf"

Kalbasi, M., Racz, G.J., Loewen-rudgers, L.A., 1978. Mechanism of zinc adsorption by iron and aluminum oxides. Soil Sci. 125.

Katyal, J.C., Sharma, B.D., 1991. DTPA-extractable and total Zn, Cu, Mn, and Fe in Indian soils and their association with some soil properties. Geoderma 49, 165-179. 
Kennou, B., El Meray, M., Romane, A., Arjouni, Y., 2015. Assessment of heavy metal availability (Pb, $\mathrm{Cu}, \mathrm{Cr}, \mathrm{Cd}, \mathrm{Zn})$ and speciation in contaminated soils and sediment of discharge by sequential extraction. Environ. Earth Sci. 74, 5849-5858.

Kim, R.-Y., Yoon, J.-K., Kim, T.-S., Yang, J.E., Owens, G., Kim, K.-R., 2015. Bioavailability of heavy metals in soils: definitions and practical implementation - a critical review. Environ. Geochem. Health 37, 1041-1061.

Kim, R.Y., Yoon, J.K., Kim, T.S., Yang, J.E., Owens, G., Kim, K.R., 2015. Bioavailability of heavy metals in soils: definitions and practical implementation — a critical review. Environ. Geochem. Health 37, 1041-1061.

Kuhlbusch TA.J., Crutzen PJ., 2018. Toward a global estimate of black carbon in residues of vegetation fires representing a sink of atmospheric $\mathrm{CO} 2$ and a source of O2. Global Biogeochem. Cycles 9, 491-501.

Kumar, M., 2016. Understanding the remobilization of copper, zinc, cadmium and lead due to ageing through sequential extraction and isotopic exchangeability. Environ. Monit. Assess. 188.

Leleyter, L., Rousseau, C., Biree, L., Baraud, F., 2012. Comparison of EDTA, HCl and sequential extraction procedures, for selected metals $(\mathrm{Cu}, \mathrm{Mn}, \mathrm{Pb}, \mathrm{Zn})$, in soils, riverine and marine sediments. J. Geochemical Explor. 116-117, 51-59.

Lin, Q., Shen, K., Zhao, H., Li, W., 2008. Growth response of Zea mays L . in pyrene - copper cocontaminated soil and the fate of pollutants. J Hazard Mater. 150, 515-521.

Lin, Z., Puls, R.W., 2000. Adsorption, desorption and oxidation of arsenic affected by clay minerals and aging process. Environ. Geol. 39, 753-759.

Liu, G., Wang, J., Zhang, E., Hou, J., Liu, X., 2016. Heavy metal speciation and risk assessment in dry land and paddy soils near mining areas at Southern China. Environ. Sci. Pollut. Res. 23, 8709-8720.

Lu, K., Yang, X., Gielen, G., Bolan, N., Sik, Y., Khan, N., Xu, S., Yuan, G., Chen, X., Zhang, X., Liu, D., Song, Z., Liu, X., Wang, H., 2017. Effect of bamboo and rice straw biochars on the mobility and redistribution of heavy metals ( $\mathrm{Cd}, \mathrm{Cu}, \mathrm{Pb}$ and $\mathrm{Zn}$ ) in contaminated soil. J. Environ. Manage. 186, 
$285-292$.

Ma, L., Zhong, H., Wu, Y.G., 2015. Effects of metal-soil contact time on the extraction of mercury from soils. Bull. Environ. Contam. Toxicol. 94, 399-406.

Maechler M., Hubert M., Rousseeuw. 2012. Cluster: Cluster analysis basics and extensions. Code, 78pp Mehta, N., Dino, G.A., Ajmone-Marsan, F., Lasagna, M., Romè, C., De Luca, D.A., 2018. Extractive waste management: A risk analysis approach. Sci. Total Environ. 622-623, 900-912.

Menegário, A.A., Yabuki, L.N.M., Luko, K.S., Williams, P.N., Blackburn, D.M., 2017. Use of diffusive gradient in thin films for in situ measurements: A review on the progress in chemical fractionation, speciation and bioavailability of metals in waters. Anal. Chim. Acta 983, 54-66.

Millward, R.N., Carman, K.R., Fleeger, J.W., Gambrell, R.P., Portier, R., 2004. Mixtures of metals and hydrocarbons elicit complex responses by a benthic invertebrate community. J. Exp. Mar. Bio. Ecol. $310,115-130$.

Mukwaturi, M., Lin, C., 2015. Mobilization of heavy metals from urban contaminated soils under water inundation conditions. J. Hazard. Mater. 285, 445-452.

Naidu, R., Channey, R., McConnell, S., Johnston, N., Semple, K.T., McGrath, S., Dries, V., Nathanail, P., Harmsen, J., Pruszinski, A., MacMillan, J., Palanisami, T., 2015. Towards bioavailability-based soil criteria: past, present and future perspectives. Environ. Sci. Pollut. Res. 22, 8779-8785.

Naji, A., Ismail, A., Ismail, A.R., 2010. Chemical speciation and contamination assessment of $\mathrm{Zn}$ and $\mathrm{Cd}$ by sequential extraction in surface sediment of Klang River, Malaysia. Microchem. J. 95, 285-292.

Oksanen, A.J., Blanchet, F.G., Kindt, R., Legen-, P., Minchin, P.R., Hara, R.B.O., Simpson, G.L., Soly-, P., Stevens, M.H.H., Wagner, H., 2011. Package ‘ vegan .'

Ortega-Calvo, J.-J.J., Harmsen, J., Parsons, J.R., Semple, K.T., Aitken, M.D., Ajao, C., Eadsforth, C., Galay-Burgos, M., Naidu, R., Oliver, R., Peijnenburg, W.J.G.M.G.M., Römbke, J., Streck, G., Versonnen, B., 2015. From Bioavailability Science to Regulation of Organic Chemicals. Environ. Sci. Technol. 49, 10255-10264.

Palumbo-Roe, B., Wragg, J., Cave, M.R., Wagner, D., 2013. Effect of weathering product assemblages 
on $\mathrm{Pb}$ bioaccessibility in mine waste: Implications for risk management. Environ. Sci. Pollut. Res. 20, 7699-7710.

Parker, R., Bolam, T., Barry, J., Mason, C., Kroger, S., Warford, L., Silburn, B., Sivyer, D., Birchenough, S., Mayes, A., Fones, G.R., 2016. The application of Diffusive Gradients in Thin Films (DGT) for improved understanding of metal behaviour at marine disposal sites. Sci Total Env. 575, 1074-1086.

Pinto, E., Almeida, A.A., Ferreira, I.M.P.L.V.O., 2015. Assessment of metal(loid)s phytoavailability in intensive agricultural soils by the application of single extractions to rhizosphere soil. Ecotoxicol. Environ. Saf. 113, 418-424.

Prokop, Z., Cupr, P., Zlevorova-Zlamalikova, V., Komarek, J., Dusek, L., Holoubek, I., 2003. Mobility, bioavailability, and toxic effects of cadmium in soil samples. Environ. Res. 91, 119-126.

Qian, P., Schoenau, J.J., 2002. Practical applications of ion exchange resins in agricultural and environmental soil research. Can. J. Soil Sci. 82, 9-21.

Reis, A.P., Patinha, C., Wragg, J., Dias, A.C., Cave, M., Sousa, A.J., Costa, C., Cachada, A., Ferreira da Silva, E., Rocha, F., Duarte, A., 2014. Geochemistry, mineralogy, solid-phase fractionation and oral bioaccessibility of lead in urban soils of Lisbon. Environ. Geochem. Health 36, 867-881.

Ren, J., Williams, P.N., Luo, J., Ma, H., Wang, X., 2015. Sediment metal bioavailability in Lake Taihu, China: evaluation of sequential extraction, DGT, and PBET techniques. Environ. Sci. Pollut. Res. 22, 12919-12928.

Ribeiro, A.B., Mexia, J.T., 1997. A dynamic model for the electrokinetic removal of copper from a polluted soil. J. Hazard. Mater. 56, 257-271.

Risdon G., Pollard S.J.T., Brassington K.J., McEwan J.N., Paton G., Semple K., Coulon F. 2008.

Development of an analytical procedure for weathered hydrocarbon contaminated soils within a UK risk-based framework. Analytical Chemistry. 80: 7090-7096.

Rosado, D., Usero, J., Morillo, J., 2016. Ability of 3 extraction methods (BCR, Tessier and protease K) to estimate bioavailable metals in sediments from Huelva estuary (Southwestern Spain). Mar. Pollut. Bull. 102, 65-71. 
Saeed, K.A., 2012. Interferences of Cement Based- Solidification / Stabilization and Heavy Metals : A Review 2555-2565.

Saison, C., Perrin-Ganier, C., Amellal, S., Morel, J.-L., Schiavon, M., 2004. Effect of metals on the adsorption and extractability of 14C-phenanthrene in soils. Chemosphere 55, 477-485.

Sakan, S., Popović, A., Škrivanj, S., Sakan, N., Đorđević, D., 2016. Comparison of single extraction procedures and the application of an index for the assessment of heavy metal bioavailability in river sediments. Environ. Sci. Pollut. Res. 23, 21485-21500.

Sarkar, B., 2002. Heavy Metals In The Environment. Taylor \& Francis.

Shen, G., Lu, Y., 2005. Interaction of polycyclic aromatic hydrocarbons and heavy metals on soil enzyme $61,1175-1182$.

Soukup, D., 2013. Behavior of Arsenic and Selenium in Soils and Sediments.

Sungur, A., Soylak, M., Ozcan, H., 2014. Investigation of heavy metal mobility and availability by the BCR sequential extraction procedure: Relationship between soil properties and heavy metals availability. Chem. Speciat. Bioavailab. 26, 219-230.

Suresh, G., Ramasamy, V., Meenakshisundaram, V., Venkatachalapathy, R., Ponnusamy, V., 2011. Influence of mineralogical and heavy metal composition on natural radionuclide concentrations in the river sediments. Appl. Radiat. Isot. 69, 1466-1474.

Suresh, G., Sutharsan, P., Ramasamy, V., Venkatachalapathy, R., 2012. Assessment of spatial distribution and potential ecological risk of the heavy metals in relation to granulometric contents of Veeranam lake sediments, India. Ecotoxicol. Environ. Saf. 84, 117-124.

Tóth, G., Hermann, T., Szatmári, G., Pásztor, L., 2016. Maps of heavy metals in the soils of the European Union and proposed priority areas for detailed assessment. Sci. Total Environ. 565, 1054-1062.

Tuor, U.I., 1990. Oxidation Reduction. Soil Chem. 529, 224-231.

Venegas, A., Rigol, A., Vidal, M., 2016. Effect of ageing on the availability of heavy metals in soils amended with compost and biochar: evaluation of changes in soil and amendment properties. Environ. Sci. Pollut. Res. 23, 20619-20627. 
Vodyanitskii, Y.N., Savichev, A.T., 2017. Magnetite contamination of urban soils in European Russia. Ann. Agrar. Sci. 15, 155-162.

Ward, J.H., 1963. Hierarchical Grouping to Optimize an Objective Function. J. Am. Stat. Assoc. 58, 236244.

Wawra, A., Friesl-hanl, W., Puschenreiter, M., Soja, G., Reichenauer, T., Roithner, C., Watzinger, A., 2018. Degradation of polycyclic aromatic hydrocarbons in a mixed contaminated soil supported by phytostabilisation, organic and inorganic soil additives. Sci. Total Environ. 628-629, 1287-1295.

Wickham H. 2007. Reshaping data with the reshape package. J Stat Softw. 21: 1-20.

Wragg, J., Cave, M., Gregory, S., 2014. The Solid Phase Distribution and Bioaccessibility of Arsenic , Chromium, and Nickel in Natural Ironstone Soils in the UK 2014.

Wuana, R. a, Okieimen, F.E., Vesuwe, R.N., 2014. Mixed contaminant interactions in soil : Implications for bioavailability, risk assessment and remediation. Afr. J. Environ. Sci. Technol 8, 691-706.

Wuana, R.A., Okieimen, F.E., 2011. Heavy metals in contaminated soils: a review of sources, chemistry, risks and best available strategies for remediation. ISRN Ecol. 2011, 1-20.

Zhang, W., Zhuang, L., Yuan, Y., Tong, L., Tsang, D.C.W., 2011. Enhancement of phenanthrene adsorption on a clayey soil and clay minerals by coexisting lead or cadmium. Chemosphere 83, 302310. 

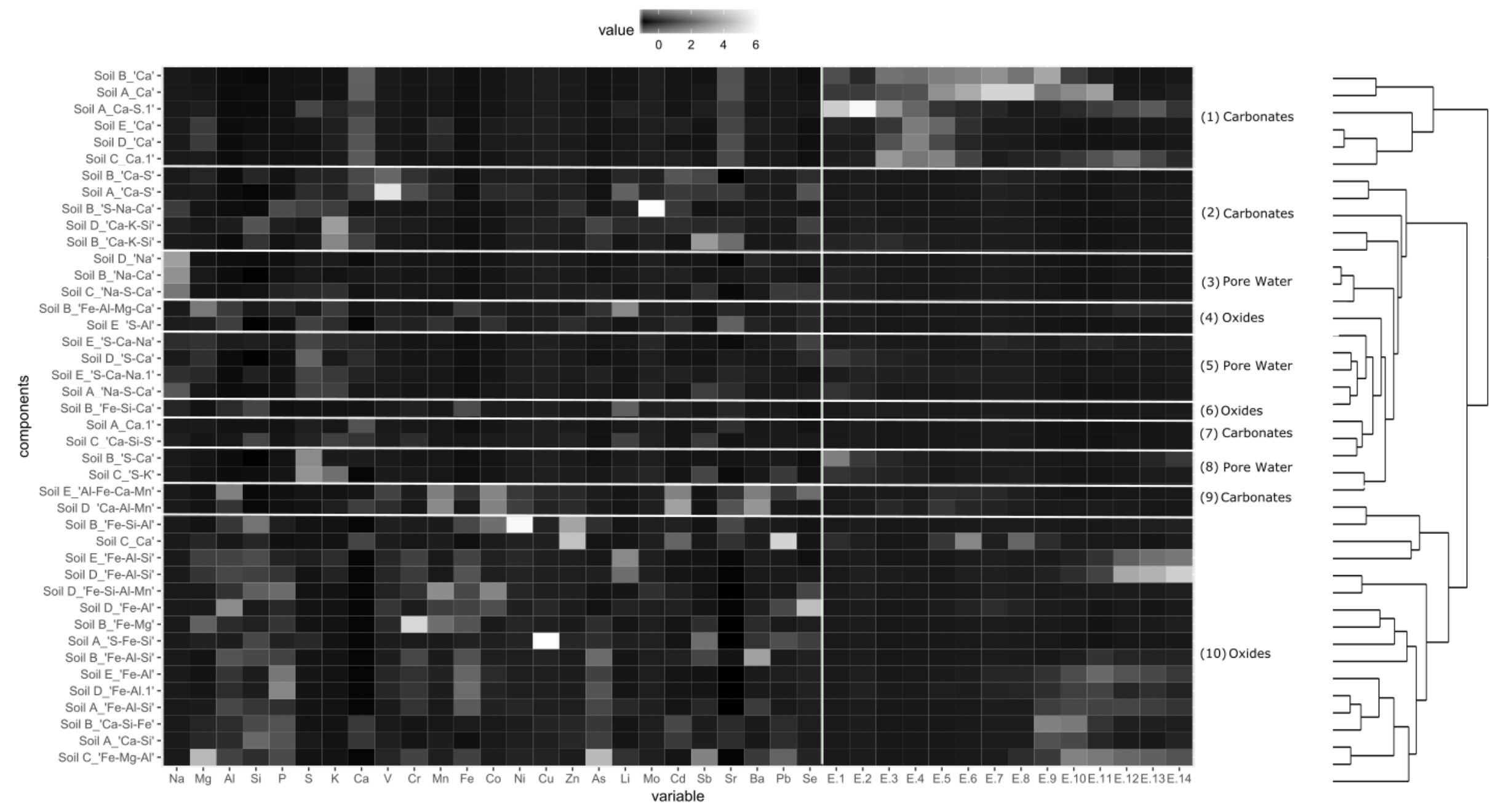

Figure 1: Heatmap and associated clustergram for CISED extraction data for a selection of test soils. The horizontal white lines divide the heatmap into the 10 different clusters, The vertical white line divides the elements composition data on the left side (e.g Na, Mg, Al) from the extraction number data $\left(E_{1}\right.$ to $\left.E_{14}\right)$ on the right side. A high proportion of each component and an indication of its composition are shown by a white or pale grey colouration

with

a

low

proportion

as

dark

grey

or

black 

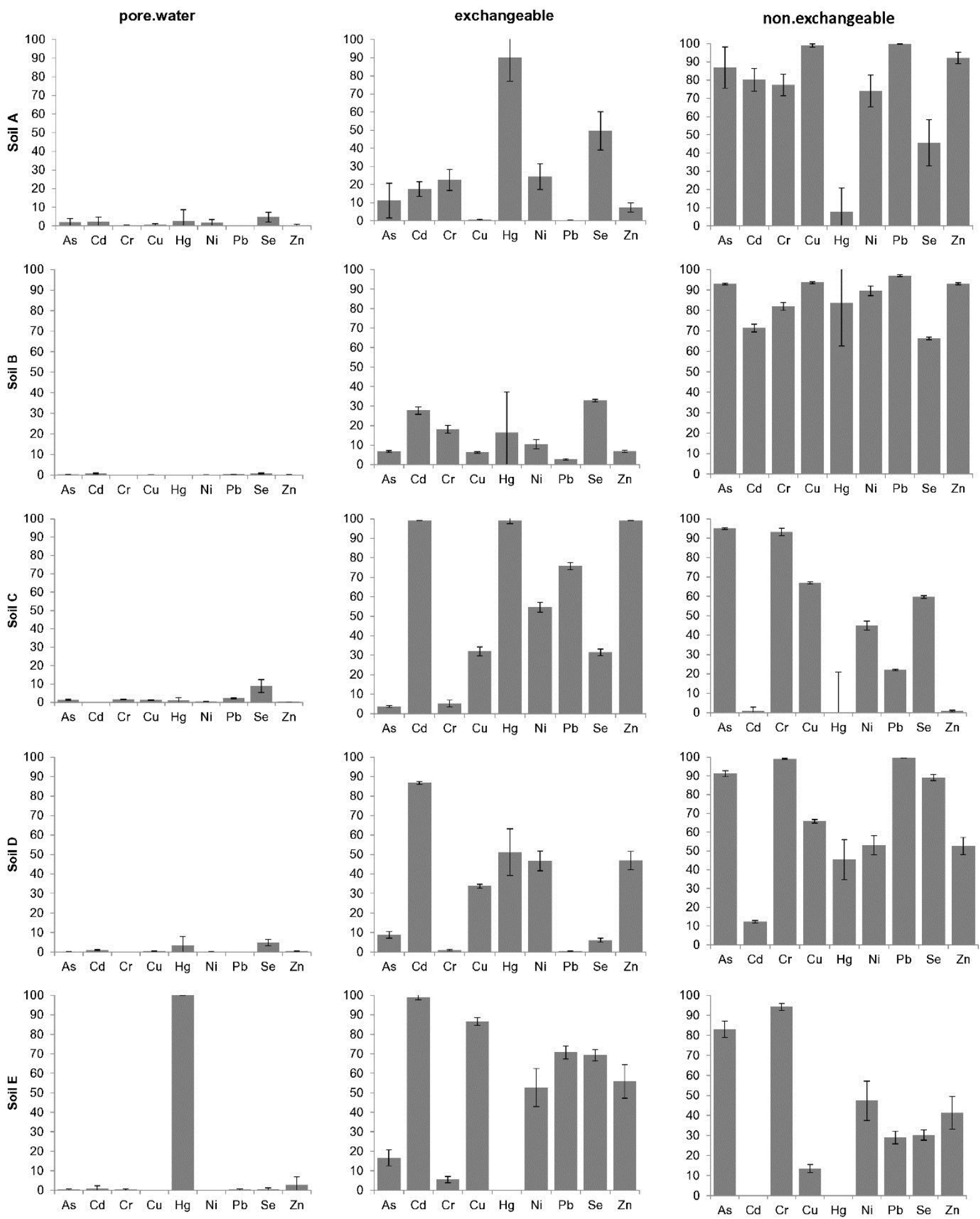

Figure 2: Overall HMs/ metalloids distribution for Soil A, Soil B, Soil C, soil D, and Soil E across the 7 conditions for all sampling times (T0, 6, and 12 months) expressed as percentage. Concentrations have been averaged across time and conditions in order to provide an overview of the overall metal behaviour. 

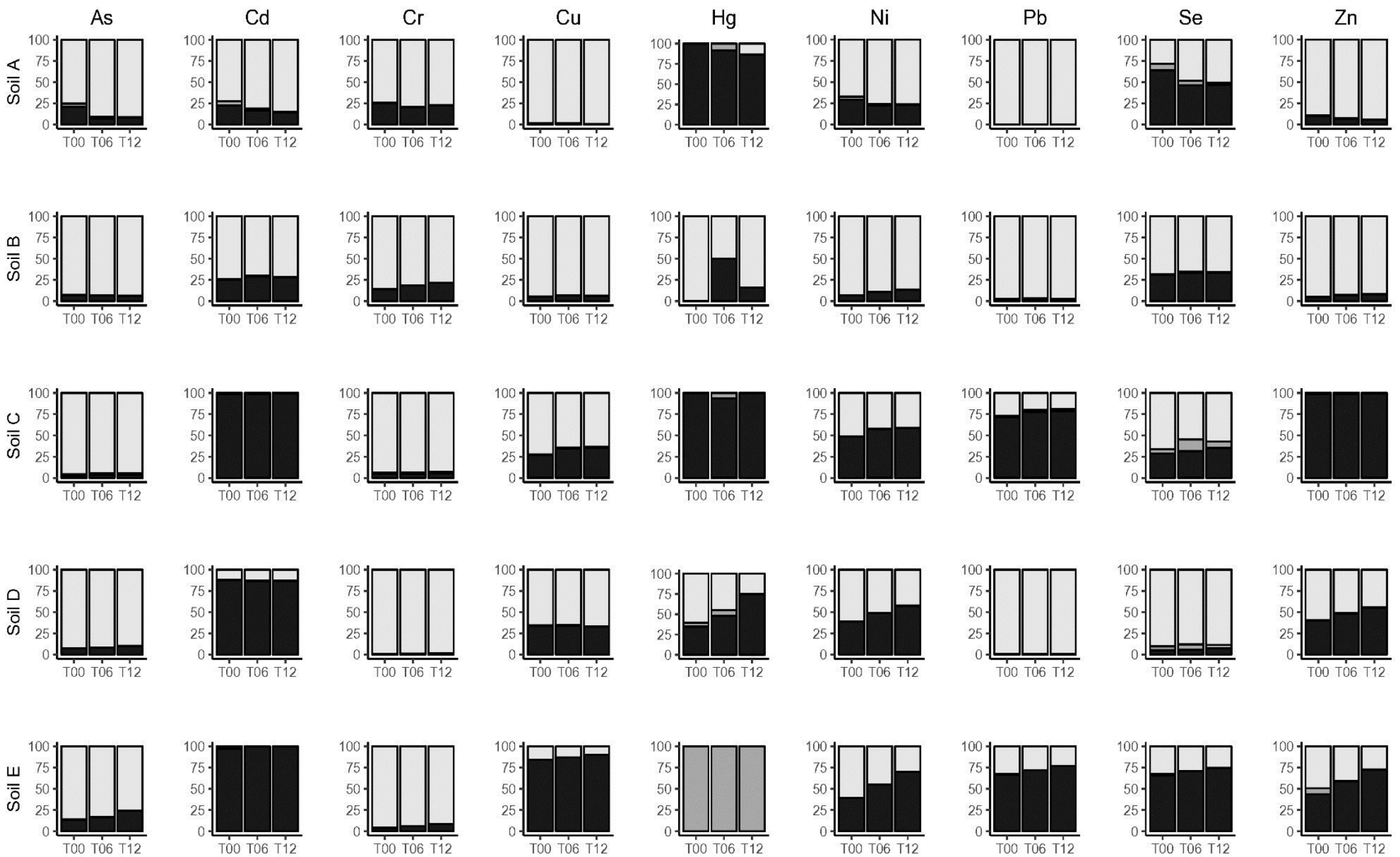

$\square$ non.exchangeable_percent $\square$ pore.water_percent

exchangeable_percent

Figure 3 : Heavy metals and metalloids distribution expressed as percentage (pore water, exchangeable, and non-exchangeable), within the 5 soil

\begin{abstract}
T0,
\end{abstract}
6 and

12 months. 
Table 1: Soils samples and soil characteristics used in the mesocosms experimental setup

\begin{tabular}{lllll}
\hline Soil & Treatment & Soil type & Contamination type & Soil matrix \\
\hline Soil A & Pre- treatment* & & & \\
Soil B & Post- treatment** & Industrial & $\begin{array}{l}\mathrm{TPHs}>1000 \mathrm{mg} / \mathrm{kg}(\mathrm{high}), \\
\mathrm{HMs}>800 \mathrm{mg} / \mathrm{kg}\end{array}$ & Sandy loam \\
& & & & \\
& & & $\mathrm{TPHs}<1000 \mathrm{mg} / \mathrm{kg}$ (medium), & Sandy loam \\
Soil C & No treatment & Industrial & $\mathrm{HMs}>6200 \mathrm{mg} / \mathrm{kg}$ & \\
& & & & \\
& & & & \\
Soil D & No treatment & Rural & $\mathrm{TPHs}<500 \mathrm{mg} / \mathrm{kg}(\mathrm{low})$, & Clay loam \\
Soil E & No treatment & & $\mathrm{HMs}>800 \mathrm{mg} / \mathrm{kg}$ & \\
\hline
\end{tabular}
TPHs: total petroleum hydrocarbons, HMs: heavy metals

* No stabiliser, ** application of cement stabiliser

Table 2: Experimental design, conditions applied to all soils

\begin{tabular}{cccc} 
Condition & pH & Temperature & Moisture content \\
\hline Cond 1 & buffered to 6-7 & $20^{\circ} \mathrm{C}$ & As received \\
Cond 2 & constant acid rain simulation $(\mathrm{pH} \mathrm{4.5)}$ & $20^{\circ} \mathrm{C}$ & As received \\
Cond 3 & As received & $20^{\circ} \mathrm{C}$ & $20 \%$ WHC \\
Cond 4 & As received & $20^{\circ} \mathrm{C}$ & $70 \%$ WHC \\
Cond 5 & As received & $20^{\circ} \mathrm{C}$ & As received \\
Cond 6 & As received & Outdoor & As received \\
Cond 7 & As received & $4{ }^{\circ} \mathrm{C}$ & As received \\
\hline
\end{tabular}

Cond: condition, WHC: Water Holding Capacity 
Table 3: Sequential extraction steps

\begin{tabular}{ccccccc}
\hline $\begin{array}{c}\text { Extraction } \\
\text { number }\end{array}$ & $\begin{array}{c}\text { Solution } \\
\text { number }\end{array}$ & $\begin{array}{c}\text { Concentration } \\
(\mathrm{M})\end{array}$ & $\begin{array}{c}\text { Deionised } \\
\text { water }\end{array}$ & $\begin{array}{c}\text { Volume } \\
\mathrm{HNO}_{3} \\
(\mathrm{ml})\end{array}$ & $\begin{array}{c}\text { Volume } \\
\mathrm{H}_{2} \mathrm{O}_{2} \\
(\mathrm{ml})\end{array}$ & $\begin{array}{c}\text { Total } \\
\text { volume } \\
(\mathrm{ml})\end{array}$ \\
$\mathrm{E}_{1-2}$ & Sol 1 & 0.00 & 10.0 & 0.00 & 0.00 & 10.00 \\
$\mathrm{E}_{3-4}$ & Sol 2 & 0.01 & 0.00 & 10.00 & 0.00 & 10.00 \\
$\mathrm{E}_{5-6}$ & Sol 3 & 0.05 & 0.00 & 10.00 & 0.00 & 10.00 \\
$\mathrm{E}_{7-8}$ & Sol 4 & 0.10 & 0.00 & 9.75 & 0.25 & 10.00 \\
$\mathrm{E}_{9-10}$ & Sol 5 & 0.50 & 0.00 & 9.50 & 0.50 & 10.00 \\
$\mathrm{E}_{11-12}$ & Sol 6 & 1.00 & 0.00 & 9.25 & 0.75 & 10.00 \\
$\mathrm{E}_{13-14}$ & Sol 7 & 5.00 & 0.00 & 9.00 & 1.00 & 10.00 \\
\hline
\end{tabular}


Table 4: Physicochemical properties of the five soil samples including pseudo-total heavy metals/metalloids and total petroleum hydrocarbon concentrations

\begin{tabular}{|c|c|c|c|c|c|c|}
\hline \multirow[b]{2}{*}{ Characteristics } & \multirow[b]{2}{*}{ Analysis } & \multicolumn{3}{|c|}{ Industrial } & \multicolumn{2}{|c|}{ Rural } \\
\hline & & Soil A & Soil B & Soil C & Soil D & Soil E \\
\hline \multirow{8}{*}{ Nutrients } & Total N (\%) & 0.07 & 0.08 & 0.12 & 0.23 & 0.25 \\
\hline & Total C (\%) & 4.00 & 4.14 & 3.87 & 2.39 & 2.78 \\
\hline & Total P (mg/kg) & 453.37 & 433.73 & 499.60 & 798.59 & 801.12 \\
\hline & available $\mathrm{P}(\mathrm{mg} / \mathrm{kg})$ & 31.55 & 30.55 & 42.18 & 35.22 & 36.72 \\
\hline & $\begin{array}{l}\text { Dry matter content } \mathrm{W}_{\mathrm{dm}} \\
(\%)\end{array}$ & 78.40 & 76.37 & 79.88 & 68.24 & 68.28 \\
\hline & Water content $(\%)$ & 27.55 & 30.94 & 25.19 & 46.53 & 46.46 \\
\hline & $\mathrm{pH}$ & 9.71 & 9.56 & 9.22 & 7.99 & 7.54 \\
\hline & LOI $(\%)$ & 4.28 & 3.97 & 5.44 & 5.99 & 6.49 \\
\hline \multirow{5}{*}{ Particle size } & $\% 212 \mu \mathrm{m}$ (Medium Sand) & 29.86 & 33.41 & 34.58 & 14.90 & 14.46 \\
\hline & $\% 63 \mu \mathrm{m}($ Fine Sand $)$ & 30.37 & 27.04 & 20.24 & 11.70 & 11.29 \\
\hline & Overall sand content & 72.11 & 74.10 & 71.68 & 30.16 & 30.10 \\
\hline & $\begin{array}{l}\% 0.002 \mathrm{~mm}-0.063 \mathrm{~mm} \\
\text { (Silt) }\end{array}$ & 19.67 & 16.70 & 16.14 & 40.57 & 36.07 \\
\hline & $\%<0.002 \mathrm{~mm}$ (Clay) & 8.22 & 9.20 & 12.17 & 29.28 & 33.83 \\
\hline
\end{tabular}




\begin{tabular}{|c|c|c|c|c|c|c|}
\hline \multirow{7}{*}{$\begin{array}{l}\text { Heavy metals } \\
\text { and metalloids } \\
\text { pseudo-total } \\
\text { concentrations } \\
(\mathrm{mg} / \mathrm{kg}) *\end{array}$} & As & $1.38-22.05$ & $4.13-22.4$ & $3.31-46.99$ & $3.95-25.89$ & $5.88-33.29$ \\
\hline & $\mathrm{Cd}$ & $0.08-3.6$ & $0.26-2.29$ & $0.27-1.9$ & $0.05-0.4$ & $0.08-0.33$ \\
\hline & $\mathrm{Cr}$ & $3.08-44.02$ & $8.7-99.99$ & $5.2-51.23$ & $7.7-85.17$ & $19.93-61.81$ \\
\hline & $\mathrm{Cu}$ & $5.19-169.82$ & $10.42-99.08$ & $9.25-128.08$ & $4.01-34.28$ & $8.47-30.49$ \\
\hline & $\mathrm{Ni}$ & $2.16-29.76$ & $6.39-34.88$ & $4.1-36.54$ & $7.04-49.14$ & $10.64-34.44$ \\
\hline & $\mathrm{Pb}$ & $18.49-794.1$ & $9.21-672.67$ & $\begin{array}{l}337.38- \\
6603.57\end{array}$ & $11.51-66.85$ & $20.44-59.73$ \\
\hline & $\mathrm{Zn}$ & $15.42-272.17$ & $66.2-281.63$ & $277.81-3527.2$ & $\begin{array}{l}30.03- \\
156.62 \\
\end{array}$ & $\begin{array}{l}44.57- \\
130.83 \\
\end{array}$ \\
\hline \multirow{2}{*}{$\begin{array}{c}\text { Petroleum } \\
\text { hydrocarbons } \\
\text { total } \\
\text { concentrations } \\
(\mathrm{mg} / \mathrm{kg})^{*}\end{array}$} & TOT ALKs & $82.45-505.22$ & $49-187.78$ & $82.91-460.78$ & $\begin{array}{l}79.22- \\
432.51\end{array}$ & $78-258.48$ \\
\hline & TOT PAHs & $\begin{array}{l}195.55- \\
2770.11\end{array}$ & $\begin{array}{l}122.84- \\
1146.95\end{array}$ & $8.44-244$ & $0.36-401.9$ & $0.6-363.37$ \\
\hline
\end{tabular}

*across all condition tested and rime points analysed

$\mathrm{N}$ : nitrogen, C: carbon, P: phosphorous, WHC: water holding capacity, LOI: loss of ignition, As: arsenic, Cd: cadmium, Cr: chromium, Cu: copper, Hg: mercury, Ni: nickel, Pb: lead, Se: selenium, Zn: zinc, HMs: heavy metals, ALKs: alkanes, PAHs: Polycyclic aromatic hydrocarbons.. 
Appendix - Insights into mixed contaminants interactions and its implication for heavy metals and metalloids mobility, bioavailability, and risk assessment - Cipullo et al.

Table A1: Descriptive statistics for metals and concentrations (expressed in $\mathrm{mg} / \mathrm{kg}$ ), obtained from replicates CISED sequential extraction of guidance materials $\left(\mathrm{BGS}_{102}\right)$.

\begin{tabular}{|c|c|c|c|c|c|c|c|c|c|c|c|}
\hline Elements & $\min$ & $\max$ & range & sum & median & mean & SE.mean & CI.mean.0.95 & var & std.dev & coef.var \\
\hline $\mathrm{Al}$ & 244.59 & 379.45 & 134.87 & 1682.34 & 342.91 & 336.47 & 24.65 & 68.45 & 3039.10 & 55.13 & 0.16 \\
\hline As & 0.39 & 0.81 & 0.43 & 2.49 & 0.43 & 0.50 & 0.08 & 0.22 & 0.03 & 0.18 & 0.36 \\
\hline $\mathrm{Ba}$ & 8.45 & 10.38 & 1.93 & 47.71 & 10.18 & 9.54 & 0.44 & 1.23 & 0.98 & 0.99 & 0.10 \\
\hline $\mathrm{Ca}$ & 1108.26 & 1535.07 & 426.81 & 6375.74 & 1221.39 & 1275.15 & 72.74 & 201.95 & 26454.26 & 162.65 & 0.13 \\
\hline $\mathrm{Cd}$ & 0.02 & 0.05 & 0.03 & 0.16 & 0.03 & 0.03 & 0.00 & 0.01 & 0.00 & 0.01 & 0.33 \\
\hline $\mathrm{Co}$ & 1.37 & 1.83 & 0.46 & 8.13 & 1.72 & 1.63 & 0.09 & 0.24 & 0.04 & 0.20 & 0.12 \\
\hline $\mathrm{Cr}$ & 0.37 & 3.45 & 3.08 & 11.46 & 2.85 & 2.29 & 0.54 & 1.51 & 1.48 & 1.22 & 0.53 \\
\hline $\mathrm{Cu}$ & 0.73 & 1.24 & 0.51 & 5.12 & 1.12 & 1.02 & 0.09 & 0.26 & 0.04 & 0.21 & 0.20 \\
\hline $\mathrm{Fe}$ & 319.69 & 857.41 & 537.72 & 3392.79 & 762.15 & 678.56 & 94.22 & 261.59 & 44383.96 & 210.68 & 0.31 \\
\hline $\mathrm{K}$ & 63.99 & 107.52 & 43.54 & 435.88 & 81.22 & 87.18 & 8.39 & 23.30 & 352.23 & 18.77 & 0.22 \\
\hline $\mathrm{Li}$ & 0.24 & 0.60 & 0.36 & 2.04 & 0.46 & 0.41 & 0.07 & 0.19 & 0.02 & 0.15 & 0.37 \\
\hline $\mathrm{Mg}$ & 42.30 & 77.94 & 35.64 & 319.76 & 63.17 & 63.95 & 6.47 & 17.95 & 209.06 & 14.46 & 0.23 \\
\hline $\mathrm{Mn}$ & 364.95 & 442.46 & 77.51 & 1996.96 & 404.15 & 399.39 & 13.99 & 38.85 & 979.00 & 31.29 & 0.08 \\
\hline Mo & 0.04 & 0.38 & 0.34 & 0.95 & 0.20 & 0.19 & 0.05 & 0.15 & 0.02 & 0.12 & 0.64 \\
\hline $\mathrm{P}$ & 43.34 & 84.58 & 41.24 & 317.31 & 63.71 & 63.46 & 6.56 & 18.22 & 215.22 & 14.67 & 0.23 \\
\hline $\mathrm{Pb}$ & 2.42 & 4.07 & 1.65 & 16.28 & 3.29 & 3.26 & 0.36 & 1.00 & 0.65 & 0.81 & 0.25 \\
\hline S & 19.19 & 53.78 & 34.59 & 162.83 & 33.81 & 32.57 & 6.14 & 17.06 & 188.78 & 13.74 & 0.42 \\
\hline $\mathrm{Se}$ & 0.24 & 0.58 & 0.33 & 1.62 & 0.27 & 0.32 & 0.06 & 0.18 & 0.02 & 0.14 & 0.44 \\
\hline $\mathrm{Si}$ & 178.17 & 294.16 & 115.99 & 1204.00 & 266.29 & 240.80 & 23.00 & 63.87 & 2645.73 & 51.44 & 0.21 \\
\hline $\mathrm{Sr}$ & 2.49 & 3.03 & 0.54 & 14.19 & 2.97 & 2.84 & 0.11 & 0.31 & 0.06 & 0.25 & 0.09 \\
\hline V & 1.43 & 2.62 & 1.19 & 10.73 & 2.25 & 2.15 & 0.23 & 0.62 & 0.25 & 0.50 & 0.23 \\
\hline $\mathrm{Zn}$ & 2.79 & 5.04 & 2.26 & 20.93 & 4.36 & 4.19 & 0.37 & 1.04 & 0.70 & 0.84 & 0.20 \\
\hline
\end{tabular}

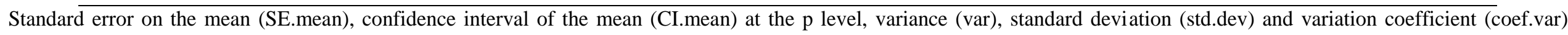
defined as the standard deviation divided by the mean. 
Table A 2: Descriptive statistics of 40 blank measurements (expressed in counts per second), and limit of detection (LOD, expressed in $\mu \mathrm{g} / \mathrm{L})$ of the analytical method applied.

\begin{tabular}{|c|c|c|c|c|c|c|c|c|c|c|c|c|c|c|}
\hline Elements & $\min$ & $\max$ & range & sum & median & mean & SE.mean & CI.mean.0.95 & std.dev & coef.var & stdev & stdev*3 & slope & LOD \\
\hline $\mathrm{Al}$ & 116.00 & 322.00 & 206.00 & 1029.09 & 148.55 & 171.52 & 30.86 & 79.33 & 75.59 & 0.44 & 51.60 & 154.80 & 136.78 & 1.130 \\
\hline As & 1.00 & 6.00 & 5.00 & 19.26 & 3.13 & 3.21 & 0.70 & 1.81 & 1.72 & 0.54 & 1.15 & 3.45 & 318.13 & 0.010 \\
\hline $\mathrm{Ba}$ & 1961.00 & 3850.00 & 1889.00 & 14543.48 & 2192.99 & 2423.91 & 290.26 & 746.14 & 710.99 & 0.29 & 411.49 & 1234.48 & 66104.02 & 0.020 \\
\hline $\mathrm{Ca}$ & 2.00 & 12.00 & 10.00 & 38.02 & 6.01 & 6.34 & 1.41 & 3.61 & 3.44 & 0.54 & 2.13 & 6.38 & 4.66 & 1.370 \\
\hline $\mathrm{Cd}$ & 5.00 & 26.00 & 21.00 & 59.79 & 7.40 & 9.97 & 3.24 & 8.33 & 7.94 & 0.80 & 3.48 & 10.45 & 6069.74 & 0.002 \\
\hline Co & 4.00 & 448.00 & 444.00 & 497.65 & 7.50 & 82.94 & 73.09 & 187.87 & 179.02 & 2.16 & 81.32 & 243.96 & 7670.48 & 0.030 \\
\hline $\mathrm{Cr}$ & 30.00 & 1450.00 & 1420.00 & 1681.42 & 43.50 & 280.24 & 234.05 & 601.65 & 573.30 & 2.05 & 214.74 & 644.23 & 3768.54 & 0.170 \\
\hline $\mathrm{Cu}$ & 145.00 & 835.00 & 690.00 & 1783.92 & 201.00 & 297.32 & 108.43 & 278.72 & 265.59 & 0.89 & 151.06 & 453.18 & 5688.58 & 0.080 \\
\hline $\mathrm{Fe}$ & 2606.00 & 30202.00 & 27596.00 & 44906.37 & 2922.75 & 7484.40 & 4545.59 & 11684.81 & 11134.37 & 1.49 & 4171.68 & 12515.05 & 2943.85 & 4.250 \\
\hline $\mathrm{Hg}$ & 79.00 & 159.00 & 80.00 & 644.52 & 101.51 & 107.42 & 11.26 & 28.95 & 27.59 & 0.26 & 16.86 & 50.58 & 6151.55 & 0.010 \\
\hline K & 7777.00 & 10162.00 & 2385.00 & 54500.85 & 9138.67 & 9083.47 & 310.91 & 799.21 & 761.56 & 0.08 & 298.63 & 895.89 & 299.74 & 2.990 \\
\hline $\mathrm{Li}$ & 391.00 & 713.00 & 322.00 & 3080.93 & 487.97 & 513.49 & 47.47 & 122.03 & 116.28 & 0.23 & 96.14 & 288.42 & 81705.34 & 0.004 \\
\hline $\mathrm{Mg}$ & 168.00 & 832.00 & 664.00 & 1826.76 & 205.75 & 304.46 & 105.88 & 272.18 & 259.36 & 0.85 & 110.08 & 330.24 & 486.38 & 0.680 \\
\hline $\mathrm{Mn}$ & 8.00 & 363.00 & 355.00 & 433.07 & 14.50 & 72.18 & 58.20 & 149.60 & 142.55 & 1.98 & 53.42 & 160.26 & 1685.35 & 0.100 \\
\hline Mo & 14.00 & 48.00 & 34.00 & 162.38 & 24.94 & 27.06 & 4.65 & 11.94 & 11.38 & 0.42 & 6.98 & 20.94 & 13962.55 & 0.001 \\
\hline $\mathrm{Ni}$ & 19.00 & 663.00 & 644.00 & 830.95 & 31.25 & 138.49 & 105.07 & 270.09 & 257.36 & 1.86 & 128.73 & 386.19 & 2241.95 & 0.170 \\
\hline $\mathrm{Na}$ & 4654.00 & 11725.00 & 7071.00 & 37876.17 & 5386.84 & 6312.70 & 1101.63 & 2831.83 & 2698.43 & 0.43 & 1631.17 & 4893.50 & 1139.94 & 4.290 \\
\hline $\mathrm{P}$ & 161.00 & 197.00 & 36.00 & 1086.09 & 182.05 & 181.02 & 4.98 & 12.81 & 12.20 & 0.07 & 8.64 & 25.93 & 8.73 & 2.970 \\
\hline $\mathrm{Pb}$ & 776.00 & 3336.00 & 2560.00 & 7708.58 & 904.50 & 1284.76 & 411.16 & 1056.93 & 1007.14 & 0.78 & 384.69 & 1154.08 & 88169.82 & 0.010 \\
\hline$S$ & 2597.00 & 3306.00 & 709.00 & 18408.34 & 3124.92 & 3068.06 & 99.74 & 256.39 & 244.31 & 0.08 & 114.11 & 342.33 & 3.06 & 111.890 \\
\hline $\mathrm{Sb}$ & 23.00 & 86.00 & 63.00 & 271.53 & 41.77 & 45.26 & 8.90 & 22.87 & 21.79 & 0.48 & 12.52 & 37.56 & 19894.58 & 0.000 \\
\hline $\mathrm{Se}$ & 2.00 & 11.00 & 9.00 & 39.51 & 6.76 & 6.59 & 1.23 & 3.16 & 3.01 & 0.46 & 2.11 & 6.33 & 24.32 & 0.260 \\
\hline $\mathrm{Si}$ & 34440.00 & 41612.00 & 7172.00 & 236813.42 & 40173.71 & 39468.90 & 1037.49 & 2666.97 & 2541.33 & 0.06 & 1046.54 & 3139.62 & 116.55 & 26.940 \\
\hline $\mathrm{Sr}$ & 732.00 & 1548.00 & 816.00 & 5612.91 & 840.45 & 935.48 & 124.52 & 320.08 & 305.00 & 0.33 & 153.70 & 461.11 & 64139.65 & 0.010 \\
\hline $\mathrm{V}$ & 1.00 & 10.00 & 9.00 & 23.28 & 3.14 & 3.88 & 1.30 & 3.33 & 3.18 & 0.82 & 1.69 & 5.06 & 2962.43 & 0.002 \\
\hline $\mathrm{Zn}$ & 39.00 & 491.00 & 452.00 & 791.95 & 65.75 & 131.99 & 72.04 & 185.19 & 176.46 & 1.34 & 74.68 & 224.05 & 494.81 & 0.450 \\
\hline
\end{tabular}

Standard error on the mean (SE.mean), confidence interval of the mean (CI.mean) at the p level, variance (var), standard deviation (std.dev) and variation coefficient (coef.var) defined as the standard deviation divided by the mean. 
Table A3: Descriptive statistics of heavy metals (HMs) and metalloids concentrations in pore water, exchangeable and non-exchangeable fraction (expressed in $\mathrm{mg} / \mathrm{kg}$ ) in the soil samples analysed (Soil A, Soil B, Soil C, Soil D, and Soil E).

\begin{tabular}{|c|c|c|c|c|c|c|c|c|c|c|}
\hline \multirow[t]{2}{*}{ Sample } & \multirow{3}{*}{$\begin{array}{c}\text { Element } \\
\text { As }\end{array}$} & \multicolumn{3}{|c|}{ Pore water } & \multicolumn{3}{|c|}{ Exchangeable } & \multicolumn{3}{|c|}{ Non-exchangeable } \\
\hline & & \multicolumn{2}{|c|}{ Range } & \multirow{2}{*}{$\begin{array}{c}\text { Median } \\
0.080\end{array}$} & \multicolumn{2}{|c|}{ Range } & \multirow{2}{*}{$\begin{array}{c}\text { Median } \\
0.599\end{array}$} & \multicolumn{2}{|c|}{ Range } & \multirow{2}{*}{$\begin{array}{c}\text { Median } \\
7.050\end{array}$} \\
\hline \multirow{9}{*}{ Soil A } & & 0.050 & - $\quad 0.113$ & & 0.494 & 0.615 & & 6.031 & 7.345 & \\
\hline & $\mathrm{Cd}$ & 0.002 & $-\quad 0.005$ & 0.003 & 0.042 & 0.051 & 0.047 & 0.216 & 0.259 & 0.234 \\
\hline & $\mathrm{Cr}$ & 0.003 & - 0.006 & 0.005 & 0.882 & 1.092 & 1.029 & 3.070 & 4.716 & 3.648 \\
\hline & $\mathrm{Cu}$ & 0.056 & $\begin{array}{l}-\quad 0.126\end{array}$ & 0.089 & 0.168 & 0.213 & 0.193 & 25.918 & $-\quad 41.040$ & 33.170 \\
\hline & $\mathrm{Hg}$ & 0.000 & $-\quad 0.000$ & 0.000 & 0.001 & 0.002 & 0.002 & 0.000 & $-\quad 0.000$ & 0.000 \\
\hline & $\mathrm{Ni}$ & 0.035 & $\begin{array}{ll}- & 0.079\end{array}$ & 0.056 & 1.256 & 1.506 & 1.388 & 4.197 & 5.605 & 4.984 \\
\hline & $\mathrm{Pb}$ & 0.000 & $\begin{array}{l}-\quad 0.000 \\
0\end{array}$ & 0.000 & 0.044 & 0.056 & 0.048 & 96.378 & $-\quad 122.121$ & 106.981 \\
\hline & $\mathrm{Se}$ & 0.033 & $-\quad 0.075$ & 0.053 & 0.691 & 0.845 & 0.791 & 0.732 & $-\quad 0.918$ & 0.864 \\
\hline & $\mathrm{Zn}$ & 0.106 & $\begin{array}{l}-\quad 0.238 \\
\end{array}$ & 0.168 & 4.769 & 5.756 & 5.320 & 70.648 & - 81.294 & 73.908 \\
\hline \multirow{9}{*}{ Soil B } & As & 0.016 & $\begin{array}{l}-\quad 0.028 \\
\end{array}$ & 0.021 & 0.542 & 0.607 & 0.582 & 7.678 & 8.684 & 7.929 \\
\hline & $\mathrm{Cd}$ & 0.004 & $\begin{array}{l}-\quad 0.008 \\
\end{array}$ & 0.006 & 0.214 & 0.256 & 0.250 & 0.582 & 0.705 & 0.656 \\
\hline & $\mathrm{Cr}$ & 0.000 & - $\quad 0.000$ & 0.000 & 1.091 & 1.354 & 1.263 & 4.910 & 6.364 & 5.375 \\
\hline & $\mathrm{Cu}$ & 0.024 & - $\quad 0.036$ & 0.029 & 2.528 & 3.079 & 2.867 & 41.476 & - $\quad 46.504$ & 43.960 \\
\hline & $\mathrm{Hg}$ & 0.000 & - $\quad 0.000$ & 0.000 & 0.001 & 0.001 & 0.001 & 0.001 & - $\quad 0.006$ & 0.002 \\
\hline & $\mathrm{Ni}$ & 0.004 & - $\quad 0.005$ & 0.004 & 0.874 & 0.990 & 0.894 & 5.945 & 9.796 & 6.501 \\
\hline & $\mathrm{Pb}$ & 0.357 & $\begin{array}{ll}- & 0.648\end{array}$ & 0.468 & 3.848 & 4.699 & 4.486 & 149.771 & - 186.686 & 171.491 \\
\hline & $\mathrm{Se}$ & 0.010 & - $\quad 0.017$ & 0.013 & 0.544 & 0.590 & 0.569 & 1.102 & $-\quad 1.229$ & 1.139 \\
\hline & $\mathrm{Zn}$ & 0.161 & $\begin{array}{l}-\quad 0.315 \\
\end{array}$ & 0.214 & 8.978 & 11.568 & 10.750 & 131.240 & $-\quad 150.798$ & 140.395 \\
\hline \multirow{6}{*}{ Soil C } & As & 0.168 & - $\quad 0.246$ & 0.192 & 0.590 & 0.741 & 0.671 & 13.142 & $-\quad 20.037$ & 16.334 \\
\hline & $\mathrm{Cd}$ & 0.000 & - $\quad 0.000$ & 0.000 & 1.129 & 1.446 & 1.340 & 0.010 & - $\quad 0.015$ & 0.012 \\
\hline & $\mathrm{Cr}$ & 0.126 & $\begin{array}{l}-\quad 0.201\end{array}$ & 0.154 & 0.390 & 0.536 & 0.472 & 7.415 & - $\quad 11.306$ & 9.216 \\
\hline & $\mathrm{Cu}$ & 0.389 & - $\quad 0.581$ & 0.461 & 12.106 & $\begin{array}{l}-\quad 15.287\end{array}$ & 14.005 & 22.493 & $-\quad 34.295$ & 27.957 \\
\hline & $\mathrm{Hg}$ & 0.000 & - $\quad 0.000$ & 0.000 & 0.007 & 0.016 & 0.009 & 0.000 & - $\quad 0.000$ & 0.000 \\
\hline & $\mathrm{Ni}$ & 0.029 & - $\quad 0.043$ & 0.036 & 5.545 & 7.054 & 6.614 & 4.092 & 6.239 & 5.086 \\
\hline
\end{tabular}




\begin{tabular}{|c|c|c|c|c|c|c|c|c|c|c|}
\hline & $\mathrm{Pb}$ & 42.420 & $\begin{array}{l}-\quad 62.902\end{array}$ & 52.165 & 1624.888 & - 2064.239 & 1891.046 & 420.330 & - 640.887 & 522.437 \\
\hline & $\mathrm{Se}$ & 0.087 & $\begin{array}{l}-\quad 0.126\end{array}$ & 0.104 & 0.437 & 0.561 & 0.510 & 0.747 & 1.139 & 0.929 \\
\hline & $\mathrm{Zn}$ & 2.052 & $\begin{array}{l}-\quad 3.118 \\
\end{array}$ & 2.540 & 1313.302 & $-\quad 1657.856$ & 1535.797 & 9.358 & - $\quad 14.268$ & 11.631 \\
\hline \multirow{9}{*}{ Soil D } & As & 0.002 & - $\quad 0.005$ & 0.004 & 0.325 & 0.385 & 0.343 & 3.094 & 4.406 & 3.622 \\
\hline & $\mathrm{Cd}$ & 0.001 & - $\quad 0.002$ & 0.002 & 0.170 & 0.204 & 0.187 & 0.024 & 0.032 & 0.028 \\
\hline & $\mathrm{Cr}$ & 0.001 & $\begin{array}{l}-\quad 0.002 \\
\end{array}$ & 0.001 & 0.060 & 0.073 & 0.063 & 4.267 & 9.207 & 5.086 \\
\hline & $\mathrm{Cu}$ & 0.048 & $\begin{array}{ll}- & 0.090\end{array}$ & 0.069 & 5.286 & 6.041 & 5.708 & 10.286 & $\begin{array}{l}-\quad 12.040 \\
-\end{array}$ & 10.661 \\
\hline & $\mathrm{Hg}$ & 0.000 & - $\quad 0.000$ & 0.000 & 0.002 & 0.003 & 0.002 & 0.001 & 0.003 & 0.001 \\
\hline & $\mathrm{Ni}$ & 0.002 & $\begin{array}{l}-\quad 0.009 \\
\end{array}$ & 0.004 & 2.759 & 3.327 & 3.047 & 2.028 & 5.379 & 2.245 \\
\hline & $\mathrm{Pb}$ & 0.000 & $\begin{array}{l}-\quad 0.000 \\
\end{array}$ & 0.000 & 0.290 & 0.340 & 0.302 & 53.687 & $-\quad 58.755$ & 56.100 \\
\hline & $\mathrm{Se}$ & 0.068 & - $\quad 0.116$ & 0.080 & 0.109 & 0.135 & 0.118 & 1.544 & 1.920 & 1.615 \\
\hline & $\mathrm{Zn}$ & 0.124 & $\begin{array}{l}-\quad 0.232 \\
\end{array}$ & 0.159 & 15.243 & 18.038 & 16.736 & 12.100 & $\begin{array}{l}-\quad 28.150 \\
\end{array}$ & 13.715 \\
\hline \multirow{9}{*}{ Soil E } & As & 0.000 & $\begin{array}{l}-\quad 0.000 \\
\end{array}$ & 0.000 & 0.600 & 0.732 & 0.646 & 2.945 & 4.349 & 3.659 \\
\hline & $\mathrm{Cd}$ & 0.000 & $\begin{array}{l}-\quad 0.000 \\
\end{array}$ & 0.000 & 0.200 & 0.231 & 0.216 & 0.000 & 0.000 & 0.000 \\
\hline & $\mathrm{Cr}$ & 0.000 & $\begin{array}{ll}- & 0.001\end{array}$ & 0.000 & 0.325 & 0.382 & 0.347 & 3.900 & 9.083 & 7.032 \\
\hline & $\mathrm{Cu}$ & 0.000 & $\begin{array}{l}-\quad 0.000 \\
\end{array}$ & 0.000 & 12.187 & 14.558 & 13.209 & 1.825 & 2.550 & 2.113 \\
\hline & $\mathrm{Hg}$ & 0.001 & - $\quad 0.034$ & 0.002 & 0.000 & 0.000 & 0.000 & 0.000 & 0.000 & 0.000 \\
\hline & $\mathrm{Ni}$ & 0.000 & $\begin{array}{l}-\quad 0.000 \\
\end{array}$ & 0.000 & 3.272 & 3.777 & 3.530 & 1.583 & 5.488 & 3.898 \\
\hline & $\mathrm{Pb}$ & 0.000 & $\begin{array}{l}-\quad 0.007 \\
\end{array}$ & 0.000 & 47.840 & 58.162 & 53.318 & 18.523 & - $\quad 26.776$ & 22.418 \\
\hline & $\mathrm{Se}$ & 0.000 & $\begin{array}{l}-\quad 0.000 \\
\end{array}$ & 0.000 & 1.071 & 1.377 & 1.261 & 0.462 & 0.645 & 0.534 \\
\hline & $\mathrm{Zn}$ & 0.001 & - $\quad 0.031$ & 0.002 & 18.681 & 21.512 & 20.115 & 9.521 & - $\quad 22.601$ & 17.437 \\
\hline
\end{tabular}

Range of measurement between different sampling times (0, 6, and 12 months) and different conditions (Cond 1-Cond 7) 
Table A4: Pearson's correlation matrix for the heavy metals and metalloids concentrations (Soil A)

\begin{tabular}{cccccccccc}
\hline & $\mathrm{Cr}$ & $\mathrm{Ni}$ & $\mathrm{Cu}$ & $\mathrm{Zn}$ & $\mathrm{As}$ & $\mathrm{Cd}$ & $\mathrm{Hg}$ & $\mathrm{Pb}$ & $\mathrm{Se}$ \\
\hline $\mathrm{Cr}$ & 1.000 & & & & & & & & \\
$\mathrm{Ni}$ & $\mathbf{0 . 9 8 0}$ & 1.000 & & & & & & & \\
$\mathrm{Cu}$ & 0.566 & 0.572 & 1.000 & & & & & & \\
$\mathrm{Zn}$ & $\mathbf{0 . 9 1 0}$ & $\mathbf{0 . 8 7 7}$ & 0.722 & 1.000 & & & & & \\
$\mathrm{As}$ & $\mathbf{0 . 9 6 5}$ & $\mathbf{0 . 9 7 7}$ & 0.618 & $\mathbf{0 . 9 3 6}$ & 1.000 & & & & \\
$\mathrm{Cd}$ & $\mathbf{0 . 9 2 6}$ & $\mathbf{0 . 9 3 3}$ & 0.669 & $\mathbf{0 . 9 7 3}$ & $\mathbf{0 . 9 6 8}$ & 1.000 & & & \\
$\mathrm{Hg}$ & 0.279 & 0.427 & -0.052 & 0.022 & 0.346 & 0.199 & 1.000 & & \\
$\mathrm{~Pb}$ & 0.837 & 0.800 & 0.800 & $\mathbf{0 . 9 8 5}$ & $\mathbf{0 . 8 7 8}$ & $\mathbf{0 . 9 3 5}$ & -0.080 & 1.000 & \\
$\mathrm{Se}$ & 0.456 & 0.600 & 0.086 & 0.195 & 0.502 & 0.383 & $\mathbf{0 . 9 5 9}$ & 0.085 & 1.000 \\
\hline
\end{tabular}

Table A5: Pearson's correlation matrix for the heavy metals and metalloids concentrations (Soil B)

\begin{tabular}{llllllllll}
\hline & $\mathrm{Cr}$ & $\mathrm{Ni}$ & $\mathrm{Cu}$ & $\mathrm{Zn}$ & $\mathrm{As}$ & $\mathrm{Cd}$ & $\mathrm{Hg}$ & $\mathrm{Pb}$ & $\mathrm{Se}$ \\
\hline $\mathrm{Cr}$ & 1.000 & & & & & & & & \\
$\mathrm{Ni}$ & 0.742 & 1.000 & & & & & & & \\
$\mathrm{Cu}$ & $\mathbf{0 . 8 9 0}$ & 0.775 & 1.000 & & & & & & \\
$\mathrm{Zn}$ & $\mathbf{0 . 8 5 9}$ & $\mathbf{0 . 9 1 8}$ & $\mathbf{0 . 9 5 9}$ & 1.000 & & & & & \\
$\mathrm{As}$ & $\mathbf{0 . 9 1 1}$ & 0.786 & $\mathbf{0 . 9 9 5}$ & $\mathbf{0 . 9 5 6}$ & 1.000 & & & & \\
$\mathrm{Cd}$ & $\mathbf{0 . 8 6 7}$ & 0.716 & $\mathbf{0 . 9 4 5}$ & $\mathbf{0 . 9 0 0}$ & $\mathbf{0 . 9 3 2}$ & 1.000 & & & \\
$\mathrm{Hg}$ & 0.304 & 0.664 & 0.360 & 0.521 & 0.359 & 0.318 & 1.000 & & \\
$\mathrm{~Pb}$ & $\mathbf{0 . 8 6 4}$ & 0.738 & $\mathbf{0 . 9 9 6}$ & $\mathbf{0 . 9 4 4}$ & $\mathbf{0 . 9 8 3}$ & $\mathbf{0 . 9 3 6}$ & 0.334 & 1.000 & \\
$\mathrm{Se}$ & $\mathbf{0 . 8 8 8}$ & 0.718 & $\mathbf{0 . 8 9 5}$ & $\mathbf{0 . 8 6 0}$ & $\mathbf{0 . 8 9 9}$ & $\mathbf{0 . 9 7 7}$ & 0.307 & $\mathbf{0 . 8 6 9}$ & 1.000 \\
\hline
\end{tabular}

Table A6: Pearson's correlation matrix for the heavy metals and metalloids concentrations (Soil C)

\begin{tabular}{cccccccccc}
\hline & $\mathrm{Cr}$ & $\mathrm{Ni}$ & $\mathrm{Cu}$ & $\mathrm{Zn}$ & $\mathrm{As}$ & $\mathrm{Cd}$ & $\mathrm{Hg}$ & $\mathrm{Pb}$ & $\mathrm{Se}$ \\
\hline $\mathrm{Cr}$ & 1.000 & & & & & & & & \\
$\mathrm{Ni}$ & 0.436 & 1.000 & & & & & & & \\
$\mathrm{Cu}$ & $\mathbf{0 . 9 0 8}$ & 0.773 & 1.000 & & & & & & \\
$\mathrm{Zn}$ & -0.424 & 0.630 & -0.005 & 1.000 & & & & & \\
$\mathrm{As}$ & $\mathbf{0 . 9 9 9}$ & 0.424 & $\mathbf{0 . 9 0 2}$ & -0.436 & 1.000 & & & & \\
$\mathrm{Cd}$ & -0.423 & 0.631 & -0.005 & $\mathbf{1 . 0 0 0}$ & -0.435 & 1.000 & & & \\
$\mathrm{Hg}$ & -0.075 & 0.198 & 0.017 & 0.280 & -0.111 & 0.275 & 1.000 & & \\
$\mathrm{~Pb}$ & -0.160 & 0.818 & 0.268 & $\mathbf{0 . 9 6 2}$ & -0.174 & $\mathbf{0 . 9 6 1}$ & 0.273 & 1.000 & \\
$\mathrm{Se}$ & $\mathbf{0 . 9 0 2}$ & 0.752 & $\mathbf{0 . 9 8 5}$ & -0.022 & $\mathbf{0 . 8 9 7}$ & -0.021 & 0.034 & 0.249 & 1.000 \\
\hline
\end{tabular}


Table A7: Pearson's correlation matrix for the heavy metals and metalloids concentrations (Soil D)

\begin{tabular}{cccccccccc}
\hline & $\mathrm{Cr}$ & $\mathrm{Ni}$ & $\mathrm{Cu}$ & $\mathrm{Zn}$ & $\mathrm{As}$ & $\mathrm{Cd}$ & $\mathrm{Hg}$ & $\mathrm{Pb}$ & $\mathrm{Se}$ \\
\hline $\mathrm{Cr}$ & 1.000 & & & & & & & & \\
$\mathrm{Ni}$ & 0.719 & 1.000 & & & & & & & \\
$\mathrm{Cu}$ & 0.810 & 0.837 & 1.000 & & & & & & \\
$\mathrm{Zn}$ & 0.706 & $\mathbf{0 . 9 9 8}$ & $\mathbf{0 . 8 5 3}$ & 1.000 & & & & & \\
$\mathrm{As}$ & $\mathbf{0 . 9 6 0}$ & 0.669 & $\mathbf{0 . 8 8 5}$ & 0.671 & 1.000 & & & & \\
$\mathrm{Cd}$ & -0.296 & 0.442 & 0.172 & 0.465 & -0.270 & 1.000 & & & \\
$\mathrm{Hg}$ & 0.577 & $\mathbf{0 . 8 9 3}$ & 0.689 & $\mathbf{0 . 8 9 0}$ & 0.514 & 0.463 & 1.000 & & \\
$\mathrm{~Pb}$ & $\mathbf{0 . 8 9 1}$ & 0.528 & $\mathbf{0 . 8 5 6}$ & 0.535 & $\mathbf{0 . 9 6 9}$ & -0.356 & 0.363 & 1.000 & \\
$\mathrm{Se}$ & $\mathbf{0 . 9 5 2}$ & 0.613 & $\mathbf{0 . 8 6 3}$ & 0.614 & $\mathbf{0 . 9 9 2}$ & -0.337 & 0.461 & $\mathbf{0 . 9 8 5}$ & 1.000 \\
\hline
\end{tabular}

Table A8: Pearson's correlation matrix for the heavy metals and metalloids concentrations (Soil E)

\begin{tabular}{cccccccccc}
\hline & $\mathrm{Cr}$ & $\mathrm{Ni}$ & $\mathrm{Cu}$ & $\mathrm{Zn}$ & $\mathrm{As}$ & $\mathrm{Cd}$ & $\mathrm{Hg}$ & $\mathrm{Pb}$ & $\mathrm{Se}$ \\
\hline $\mathrm{Cr}$ & 1.000 & & & & & & & & \\
$\mathrm{Ni}$ & 0.435 & 1.000 & & & & & & & \\
$\mathrm{Cu}$ & 0.125 & $\mathbf{0 . 9 4 6}$ & 1.000 & & & & & & \\
$\mathrm{Zn}$ & 0.372 & $\mathbf{0 . 9 9 7}$ & $\mathbf{0 . 9 6 6}$ & 1.000 & & & & & \\
$\mathrm{As}$ & $\mathbf{0 . 9 6 4}$ & 0.644 & 0.371 & 0.592 & 1.000 & & & & \\
$\mathrm{Cd}$ & 0.034 & $\mathbf{0 . 9 1 4}$ & $\mathbf{0 . 9 9 5}$ & $\mathbf{0 . 9 4 0}$ & 0.284 & 1.000 & & & \\
$\mathrm{Hg}$ & -0.067 & -0.068 & -0.055 & -0.042 & -0.073 & -0.040 & 1.000 & & \\
$\mathrm{~Pb}$ & 0.296 & $\mathbf{0 . 9 8 6}$ & $\mathbf{0 . 9 8 5}$ & $\mathbf{0 . 9 9 5}$ & 0.528 & $\mathbf{0 . 9 6 3}$ & -0.064 & 1.000 & \\
$\mathrm{Se}$ & 0.332 & $\mathbf{0 . 9 9 0}$ & $\mathbf{0 . 9 7 7}$ & $\mathbf{0 . 9 9 6}$ & 0.560 & $\mathbf{0 . 9 5 1}$ & -0.067 & $\mathbf{0 . 9 9 9}$ & 1.000 \\
\hline
\end{tabular}




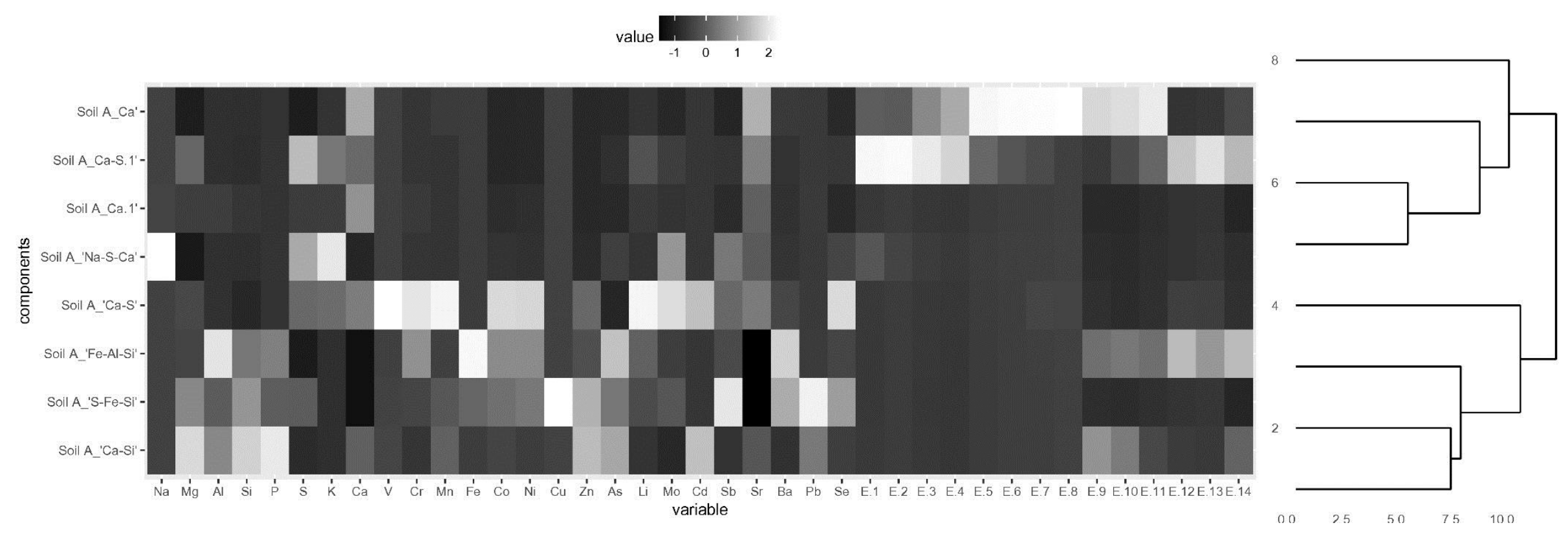

Figure A1 : Heatmap and associated hierarchical cluster for the CISED extraction data for Soil A 

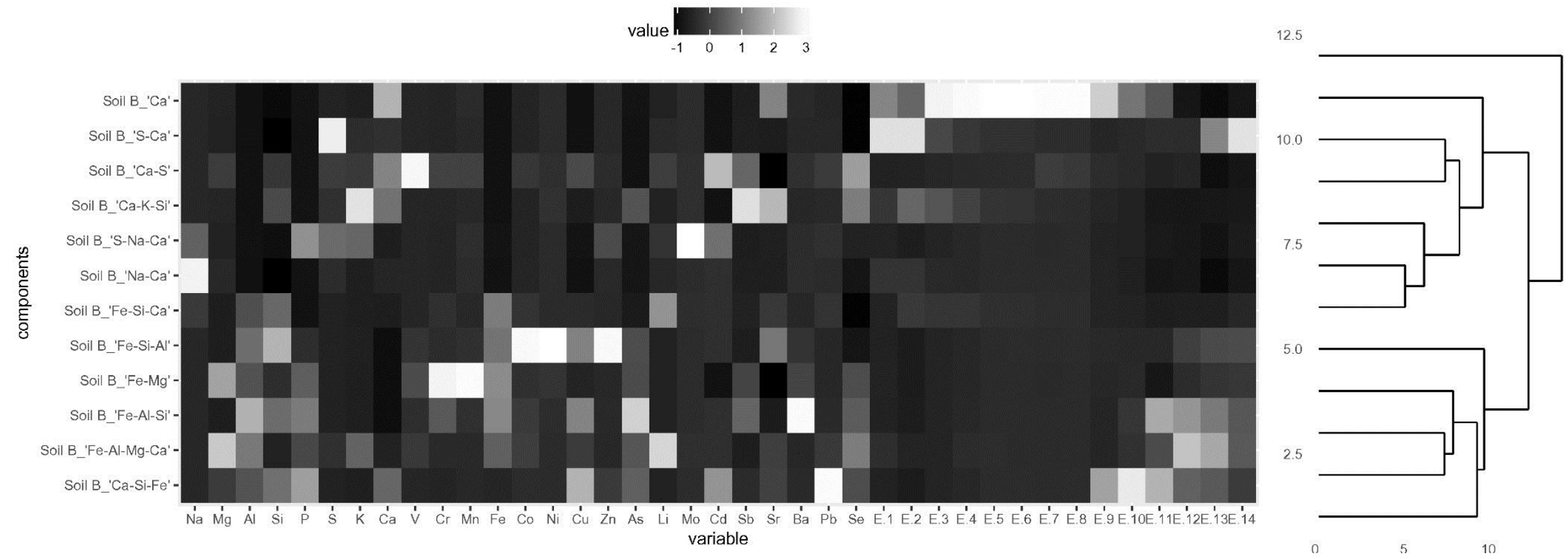

Figure A2: Heatmap and associated hierarchical cluster for the CISED extraction data for Soil B 

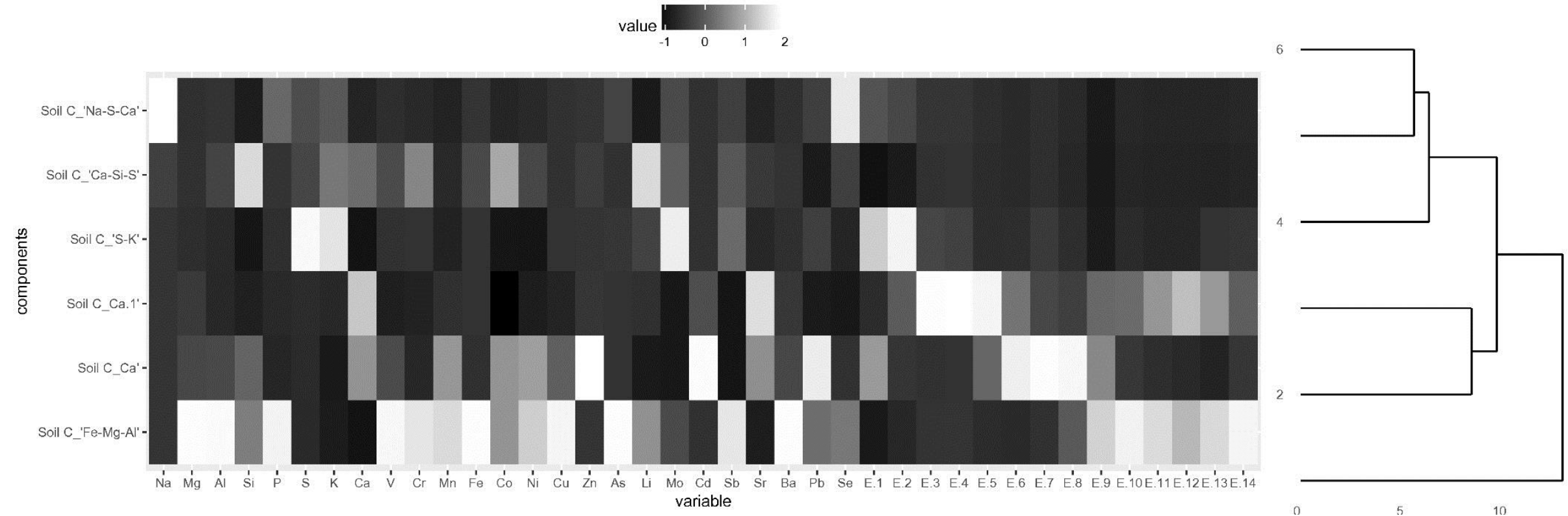

Figure A3: Heatmap and associated hierarchical cluster for the CISED extraction data for Soil C 

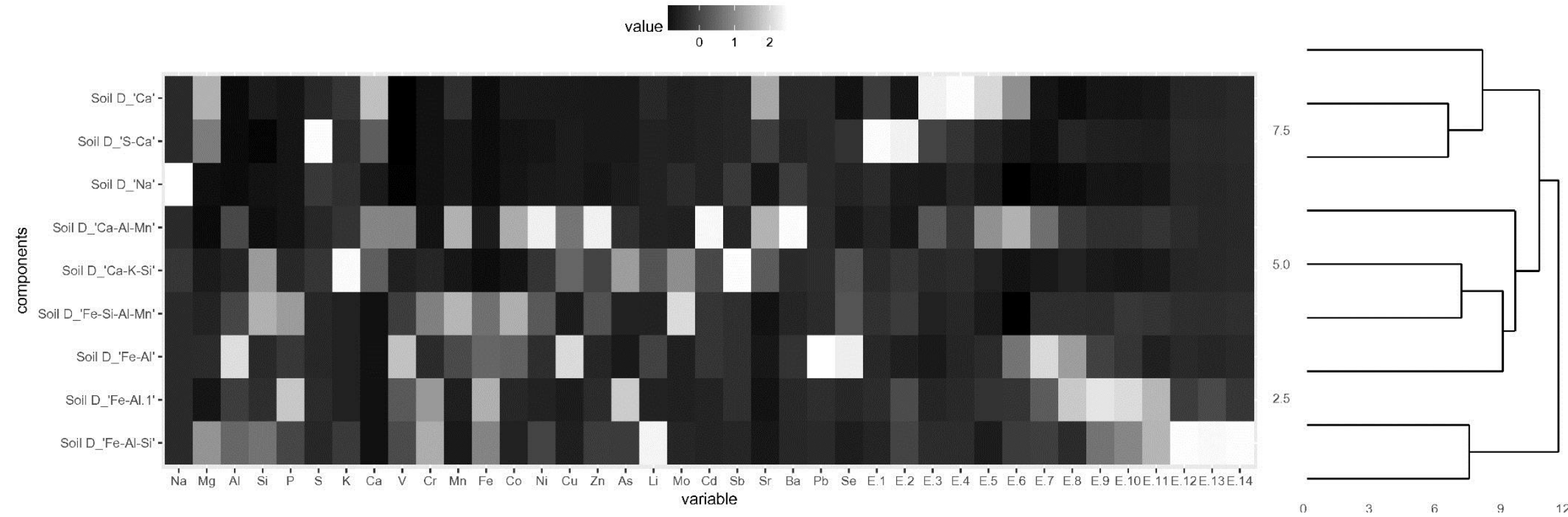

Figure A4: Heatmap and associated hierarchical cluster for the CISED extraction data for Soil D 


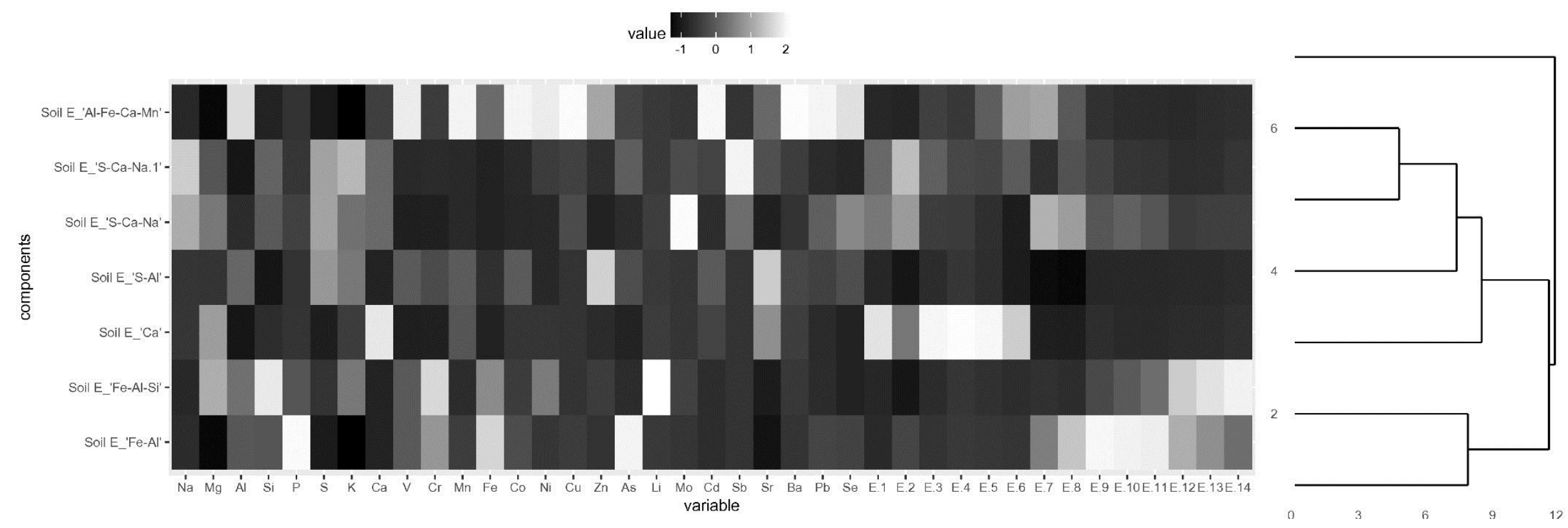

Figure A5: Heatmap and associated hierarchical cluster for the CISED extraction data for Soil E 